\title{
Cartas y otros documentos. (Memorial de los hallazgos del Sacromonte) $^{1}$
}

IGNACIO DE LAS CASAS S.I.

Miguel Córdoba SAlmerón S.I. ${ }^{2}$

\section{Palabras clave:}

Abadía del Sacromonte, Compañía de Jesús, Ignacio de las Casas, interculturalidad, libros plúmbeos, moriscos, Roberto Belarmino.
Letter and other documents (Memorial of the findings of Sacromonte)

\section{Keywords:}

Sacromonte abbey, Society of Jesus, Ignacio de las Casas, interculturality, lead books, Moriscos, Roberto Bellarmino.

\section{Notas biográficas sobre el jesuita morisco Ignacio de las Casas (1550-1608)}

Ignacio de las Casas nació en la Granada de 1550 en el seno de una familia morisca ${ }^{3}$. Su padre fue Cristóbal de las Casas, procurador y solicitador de pleitos y su madre Gracia de Mendoza. Su primera formación (1562-67) la recibió

\footnotetext{
${ }^{1}$ Este trabajo se enmarca dentro del Proyecto de investigación PEMOSJ del Ministerio de Economía y Competitividad y del Fondo Europeo de Desarrollo Regional (FEDER). Código de proyecto FFI 2015-64451-R (MINECO/FEDER) IP: Juan Antonio Senent de Frutos: «Pensamiento y tradición jesuita y su proyección en Europa y América en el desarrollo de la Modernidad desde las perspectivas de la Historia, la Antropología, Traductología y la Filosofía Jurídica, Moral y Política» de la Universidad Loyola Andalucía.

${ }^{2}$ Edición, introducción y transcripción de la documentación. Doctor en Historia del Arte (Universidad de Granada). Profesor de la Facultad de Teología, Granada. https://orcid.org/0000-00023916-3160<micordoba@gmail.com>

${ }^{3}$ Para un acercamiento más pormenorizado a la persona de Ignacio de las Casas: Medina, F. B., «La Compañía de Jesús y la minoría morisca (1545-1614)». Archivum Historicum Societatis Iesu 113, 1988, 4-9.
} 
en la Casa de la Doctrina. Esta pertenecía a los jesuitas, estaba ubicada en el barrio del Albaicín de la mencionada ciudad, y fue un encargo del arzobispo D. Pedro Guerrero para la educación de los moriscos. Fue alumno del conocido jesuita morisco Juan de Albotodo. Estudió humanidades y lógica.

Debido a las revueltas habidas por los moriscos Ignacio fue admitido en el noviciado de la Compañía de Jesús en san Andrés del Quirinal en Roma en 1572. Allí fue inscrito con el nombre Lope Álvarez. En aquella época junto a los estudios de hebreo, aprendió a leer y escribir árabe bajo la dirección de Roberto Bellarmino ${ }^{4}$. Una vez acabada su formación, en 1578, pasó a la provincia de Castilla en donde retoma sus apellidos familiares. Haría sus últimos votos en 1603.

El papa Gregorio XIII encargó a la Compañía de Jesús una misión para la visita del patriarca de Alejandría. Le fue encomendada a Juan B. Eliano, siendo su acompañante Ignacio. Posteriormente, en 1581 fue penitenciario de san Pedro para la lengua árabe ${ }^{5}$. Debido a sus conocimientos de árabe fue designado por el dicho pontífice como acompañante en otras misiones papales con otros patriarcas orientales.

En 1587 fue enviado a Valencia para el apostolado de los moriscos. Ello le llevó, para los debates con los moriscos, a repasar artes en Gandía, y cursar teología en Valencia y Alcalá (1590-93), en donde fue alumno del jesuita Francisco Suárez. Le propuso a los pontífices Gregorio XIII y Paulo V la impresión de libros árabo-cristianos y la elaboración de un catecismo para moriscos. Además profundizaría en el estudio de la problemática morisca y sus posibles soluciones. Entre 1605 y 1608 redactaría una serie de memoriales sobre la cuestión morisca en los que se mostraba crítico ante las políticas seguidas sobre la evangelización de los mismos. Así tenemos referencias de un memorial dirigido al papa Clemente VIII de 1605 y que recibió su sucesor Paulo V por fallecimiento del primero. Pero también tenemos ejemplos de memoriales ad intra de la Compañía, como la que dirige al provincial de Castilla, Cristóbal de los Cobos ${ }^{6}$.

Gracias a los mencionados conocimientos de la lengua árabe, ayudó, en Roma, a Francisco Torres a traducir los cánones árabes del Concilio de Nicea;

\footnotetext{
${ }^{4}$ Biblioteca Histórica de la Universidad de Valencia (B.H.U.V.), ms. 637/7. Carta al cardenal Roberto Bellarmino, fol. 1v.

${ }^{5}$ B.H.U.V., ms 637/7, Carta al cardenal Roberto Bellarmino, fol. 2r.

${ }^{6}$ Ver: EL ALAQUI, Youssef. «El jesuita Ignacio de las Casas y la defensa de la lengua árabe. Memorial al padre Cristóbal de los Cobos, provincial de Castilla (1607)». AREAS. Revista Internacional de Ciencias Sociales, 30 (2011), pp. 11-28; y del mismo autor: «Jesuitas y moriscos (comentario al "Segundo remedio" de Ignacio de las Casas). Travaux et Documents Hispaniques, 3 (2012), pp. 5-15.
} 
fue, en ciertas ocasiones, intérprete de árabe del Santo Oficio en Valencia (1596) y en el Consejo Supremo (1598), y tras la muerte de Jerónimo de Mur (1602), fue intérprete y calificador de la Inquisición en Valencia durante dos años.

A principios de febrero de 1597, otros investigadores hablan de junio, en una visita que está realizando a Granada, el entonces arzobispo de la ciudad, D. Pedro de Castro y Quiñones, le pide que traduzca los libros plúmbeos encontrados en el monte de Valparaíso ${ }^{7}$. Al principio se encontró favorable a su autenticidad, pero descubrió pronto el fraude y lo denunció, pues reconoció

en los libros lenguaje y conceptos islamizantes basados en el Alcorán, ejofores (...), o vaticinios moriscos de tipo mesiánico sobre la restauración del dominio árabe en España, y en otras tradiciones islámicas que circulaban entre los moriscos. Además de otros conceptos afines a arrianos y nestorianos ${ }^{8}$.

Este descubrimiento realizado por Ignacio de las Casas le condujo a la enemistad con D. Pedro de Castro, gran defensor de los hallazgos «por ser prueba irrefragable del origen jacobeo y mariano de la sede granadina $»^{9}$. Ello le llevó a la decisión de abandonar la ciudad en mayo de 1598. Aun así, Ignacio de las Casas intentará evitar la calificación de autenticidad de reliquias y libros como pretendía el arzobispo granadino.

Para ello lo denuncia a la Inquisición ante el inquisidor general D. Pedro Portocarrero -obispo de Cuenca-, escribirá a los cardenales D. César Baronio y D. Roberto Bellarmino, a los nuncios D. Camilio Caetano y a su sucesor D. Domenico Gimnasio. En 1602, al inquisidor general D. Juan de Zúñiga -obispo de

\footnotetext{
${ }^{7}$ Zótico Royo en su libro sobre las reliquias martiriales del Sacromonte le dedica un capítulo a la estancia en Granada del P. Ignacio de las Casas, al que denomina al inicio como «personaje misterioso». A lo largo del mismo nos ofrece lo que parece una visión sesgada del mismo, aunque de él se puede extraer numerosas citas documentales procedentes del Archivo de la Abadía del Sacromonte del que era entonces abad. ROYO CAMPOS, Zótico. Reliquias Martiriales y Escudo del Sacro-monte. Granada: Abadía del Sacro-monte, 1960, pp. 102-114.

${ }^{8}$ MEDINA ROJAS, Francisco de Borja. «Compañía de Jesús e islam en España (siglos XVIXVII)». Archivo Teológico Granadino, 80 (2017), pp. 186-187.

${ }^{9}$ MEDINA ROJAS, Francisco de Borja. «Compañía de..., p. 186. El profesor Manuel Barrios nos comenta que D. Pedro de Castro vertió números descalificativos sobre su oponente al que acusaba de «ser morisco, de gente baja, no soportar que los libros plúmbeos iban contra la secta de Mahoma..., de ser ignorante en lenguas orientales y en teología... y, de forma reiterada, de que su cambio respecto de los hallazgos se debió a rencores personales con él y con los de su casa, únicos que, en su extravío fanático, podían explicar el paso radical de la loa a la denuncia y a la extrema pugnacidad de su postura». BARRIOS AGUILERA, Manuel. «El castigo de la disidencia en las invenciones plúmbeas de Granada. Sacromonte versus Ignacio de las Casas». Al-Qantara, 24 (2003), p. 529.
} 
Cartagena-, a su sucesor D. Juan Bautista Acevedo -obispo de Valladolid-en 1603, al rey Felipe III en 1604, al nuevo nuncio D. Juan García Milino en 1605, al sucesor de este, D. Decio Carrafa, en 1607 y, en el mismo año, al papa Paulo V, el cual se reservaría el caso, exigiendo el envío a Roma de los libros de plomo. Un sucesor suyo, el papa Inocencio XI condenó los libros en 1682. Aunque en el siglo XVIII seguirá habiendo detractores y defensores de los mismos.

Todo este esfuerzo no consiguió evitar que en el concilio provincial granadino de 1600, en la que estuvieron presente dos jesuitas, profesores de teología de los colegios de Granada y Sevilla ${ }^{10}$. Además sus avisos no evitaron que:

la ignorancia de la lengua árabe y de la cultura islámica llevara a los teólogos católicos, entre ellos 20 jesuitas bien conocidos de los siglos XVII y XVIII, a la aceptación de los libros como del siglo I y de origen apostólico, y su utilización para probar, entre otras cosas, la venida de Santiago a España y la tesis de la Inmaculada Concepción de María y ver, en la confesión: "No hay otro Dios sino Dios, Jesús espíritu de Dios", una de las fórmulas trinitarias más antiguas..."

\section{Descubrimiento de los libros plúmbeos y las reliquias en el monte Valparaíso}

Entre 1588 y 1598 se produjo el descubrimiento en Granada de los conocidos libros plúmbeos. Estos, según el profesor Youssef El Alaqui, son una tentativa de «reescritura de la historia de los moriscos» ${ }^{12}$ por parte de dos moriscos cultos granadinos: los licenciados Alonso del Castillo y Miguel de Luna. Para el profesor Francisco de Borja Medina son: «la prueba del sincretismo islámico-cristiano de un sector morisco y de la ignorancia de la cultura islámica de los predicadores y teólogos católicos» ${ }^{13}$. Por otro lado el profesor

${ }^{10}$ En el mes de enero de 1600, antes de la celebración del Concilio Provincial, se recibió un dictamen favorable de distintas ordenes religiosas entre las que está la Compañía con el dictamen favorable del Colegio de San Hermenegildo de Sevilla firmado por los PP. Juan de Pineda, Diego Álvarez, Francisco Arias y Francisco Aleman. A.A.S., leg. 2, fol. 1180. Cfr. ROYO CAMPOS, Zótico. Reliquias Martiriales..., p. 123, nota 7. Y del Colegio de san Pablo de Granada firmaron los PP. Pedro de Vargas (rector), Pedro Bernal, Tomás Sánchez y Antonio Fernández. A.A.S., leg. 2, fol. 1049. Cfr. ROYO CAMPOS, Zótico. Reliquias Martiriales..., p. 123, nota 8. También se menciona una carta favorable del P. Francisco Suárez, «honor de Granada y de la Compañía». Cfr. ROYO CAMPOS, Zótico. Reliquias Martiriales..., p. 123.

${ }^{11}$ MEDINA ROJAS, Francisco de Borja. «Compañía de..., p. 187.

${ }^{12}$ EL ALAQUI, Youssef. «Jesuitas y moriscos..., p. 5.

${ }^{13}$ MEDINA ROJAS, Francisco de Borja. «Compañía de..., p. 186. 
Francisco Javier Martínez Medina apunta que estos libros hay que leerlos desde la teología católica ${ }^{14}$.

Estos libros circulares de plomo, del tamaño de una hostia, se encontraban unidos por un extremo en forma de libro, escritos en árabe mezclados con unos extraños caracteres, que se juzgaron en la época, como orientales y que recibieron el nombre de salomónicos. Estos se encuentran relacionados con un pergamino y unas reliquias de la Virgen que fueron encontrados tras el derribo de la Torre Turpiana para la construcción de la Catedral en 1588. Este pergamino hacía referencia a los que serían los primeros mártires cristianos granadinos del siglo primero, entre los que se encontraban dos discípulos, de orígenes árabes, de Santiago Apóstol: Cecilio Enalarabí y Tesifón Ebnatar, y que se hallaban enterrados en las cuevas del monte Valparaíso.

Desde los comienzos hubo voces que se levantaron en contra de los libros plúmbeos como el licenciado Gonzalo de Valcárcel que presentó su Discurso sobre las reliquias ante el Consejo de Castilla en mayo de $1595^{15}$. Al mismo tiempo presentó una copia al nuncio Gaetini, quien, a su vez, se la remitió al arzobispo de Granada. Junto a esta copia, el Nuncio ordenaba a D. Pedro de Castro

que no permitiese la veneración de las reliquias hasta que fueran debidamente aprobadas, ni la impresión y publicación de las láminas, ni nada que pudiera implicar un juicio favorable a las láminas y reliquias ${ }^{16}$.

Esto provocó la reacción de los defensores, entre los que destaca, el fiscal de la Real Chancillería de Granada, el Dr. Gregorio López Madera que publicará un defensorio en 1595, y posteriormente, tras la aprobación de las reliquias reelaborará su obra y lo publicará con el título: Discursos de la certidumbre de las reliquias descubiertas en Granada desde el año 1588 hasta el de 1598, de 1601 ${ }^{17}$. Sus conclusiones serían utilizados por otros autores pero sin citar la fuente ${ }^{18}$.

${ }^{14}$ MARTÍNEZ MEDINA, Francisco Javier. «Los hallazgos del sacromonte a la luz de la Historia de la Iglesia y de la Teología católica». Al-Qantara, 232 (2002), pp. 437-475; y Cristianos y musulmanes en la Granada del XVI, una ciudad intercultural. Granada: Facultad de Teología, 2016.

${ }^{15}$ De este contamos con una copia manuscrita en la Biblioteca Nacional de España. VALCARCEL, Gonzalo de. Discursos, relaciones y cartas tocantes a las cenizas, láminas y libros hallados en el Monte Sancto de Granada, sacados de sus originales. Mss 7184.

${ }^{16}$ BENÍTEZ SÁNCHEZ-BLANCO, Rafael. «El discurso del licenciado Gonzalo de Valcárcel sobre las reliquias del Sacromonte». Estudis, 28 (2002), p. 142.

${ }^{17}$ LÓPEZ DE MADERA, Gregorio. Discursos de la certidumbre de las reliquias descubiertas en Granada desde el ano [sic] de 1588 hasta el de 1598. Impreso por Sebastián de Mena, 1601.

${ }^{18}$ BENÍTEZ SÁNCHEZ-BLANCO, Rafael. «El discurso del licenciado..., p. 143. 


\section{Manuscrito de la Biblioteca Histórica de la Universidad de Valencia}

El texto de este memorial puede dar la sensación, en un primer momento, querer autojustificarse el autor en su actuación, la cual está siendo atacada por el arzobispo de Granada y por aquellos que defienden la autenticidad de las reliquias y libros plúmbeos. Posiblemente también busque respaldo ante la falta de apoyo por parte de algunos miembros de la Compañía de Jesús que también se mostraron a favor de la autenticad, como ya mencionamos con anterioridad, entre los que destacaría su maestro, desde Coímbra, el jesuita granadino Francisco Suárez.

Por eso junto a las múltiples declaraciones de humildad nos encontramos que su espíritu solo se mueve en la búsqueda de la verdad y del bien de la Iglesia y de los Reinos de España. No estamos entonces solo ante un texto de autojustificación sino que presenta un carácter político, la de conseguir que Roma interviniera en el tema de la calificación de las reliquias y libros encontrados en el monte Valparaíso, que supera incluso su afán de defenderse de los ataques.

El texto que transcribimos es el último informe o memorial que escribe, y es el dirigido al papa Paulo V en el año 1607. Es el ms. 637/7 de la Biblioteca Histórica de la Universidad de Valencia ${ }^{19}$. Este texto también lo podemos encontrar incluido en una relación de cartas y memoriales recogidos por Adán Centurión, marqués de Estepa, en la Biblioteca Apostólica Vaticana (Stamp. Barb. U. IX/55) ${ }^{20}$, también lo hallamos en la British Library (Additional 57490), que había pertenecido a Sir Thomas Kendick y en la Biblioteca Nacional de España (ms. 7187). Éste último, que procede de la Librería de D. Luis de Usoz (1875), aparece anotado al margen por un detractor del P. Ignacio de las Casas, aunque desconocemos de quién se trata. A la transcripción del manuscrito de Valencia añadiremos, para enriquecerlo, las anotaciones marginales del manuscrito de Madrid señalando, con ello, algunos de los puntos más contradictorios del memorial.

El memorial lo encontramos precedido por las cartas al cardenal César Baronio y a Roberto Bellarmino. Su estructura es la siguiente: una introducción sobre los antecedentes, tres tratados que se dividen en capítulos y una despedida.

${ }^{19}$ El manuscrito aparece citado con el número 506 en GutiérReZ del CAÑo, Marcelino, Catálogo de manuscritos existentes en la Biblioteca universitaria de Valencia, Valencia, Universidad, 1913, v. 1, pp. 183-184.

${ }^{20}$ BENÍTEZ SÁNCHEZ-BLANCO, Rafael. «De Pablo a Saulo: traducción, crítica y denuncia...», p. 405, nota 6. 
El primer tratado es la «Relación de todo lo hallado en Granada y cerca de ella» (fols. 7r-15r). Capítulo primero: «De la Caxa y lo que en ella auía» (fols. 7r-9r); capítulo segundo: «Esposición de lo contenido en el pergamino sada del capítulo 13 de los discurso que imprimió el doctor Madero deste Monte de Granada» (fols. 9r-11v); capítulo tercero: «De las láminas, cubiertas de los libros, y libros que se hallaron cerca de Granada» (fols. 11v-15r).

El segundo es «Dícense en él las contradicciones que se an [sic] puesto contra todo lo hallado» (fols. 15v-24r). Capítulo primero: «Dudas contra la Caxa y lo que en ella hauía» (fols. 15v-17r); capítulo segundo: «Otras dudas que proponen otros sobre lo mismo» (fols. 17r-21v); capítulo tercero: «Dudas que sean puesto contra las láminas sacadas del Doctor Madera» (fols. $21 \mathrm{v}-24 \mathrm{r})$.

Tercer tratado: «Tratado último de la doctrina de los libros» (fols. 24v-54r). Capítulo primero: «De los libros que yo uí y interpreté» (fols 24v-28r); capítulo segundo «Del Anillo o sello de Salomón» (fols. 28r-34v); capítulo tercero: «Del libro Historia de la Verdad del euangelio Glorioso» (fols. $34 \mathrm{v}-42 \mathrm{v}$ ); capítulo cuarto: «Del libro ensalçamiento» (fols. 42v-44v); capítulo quinto: «Del libro ilegible» (fols. 44v-46r); capítulo sexto: «Quan unidos están los libros y láminas con los huesos y con lo que de la torre y con los daños que de todo naçen» (fols. 45v-51v); capítulo séptimo: «Remedio que se pretende» (fols. 51v-54r). Los libros que comentará en estos capítulos son seis: tres descubiertos antes de que llegara a Granada -Fundamentum Ecclesiae, Excelencias de la Fe y Oración de Santiago-, y tres de los descubiertos durante su estancia en la ciudad -De la historia de la verdad del Evangelio glorioso, Ensalzamiento de la Virgen a los altos misteriosos de Dios y el Ilegible-. En la exposición separa la descripción de los hechos y del libro, pergamino o láminas, de la crítica a los mismos por parte ajena y la que el realiza.

\section{Bibliografía}

Barrios Aguilera, M., «El castigo de la disidencia en las invencione s plúmbeas de Granada. Sacromonte versus Ignacio de las Casas». Al-Qantara 24 (2003) 477-531.

Benítez Sánchez-Blanco, R., «El discurso del licenciado Gonzalo de Valcárcel sobre las reliquias del Sacromonte»: Estudis 28 (2002) 137-165.

— «De Pablo a Saulo: Traducción, crítica y denuncia de los Libros Plúmbeos por el P. Ignacio de las Casas, S.J.». Al-Qantara 23 (2002) 403-436.

Cabanelas Rodríguez, D., El morisco granadino Alonso del Castillo. Granada: Patronato de la Alhambra y Generalife, 1991. 
El Alaqui, Y., «El jesuita Ignacio de las Casas y la defensa de la lengua árabe. Memorial al padre Cristóbal de los Cobos, provincial de Castilla (1607)», AREAS. Revista Internacional de Ciencias Sociales 30 (2011) 11-28.

— «Ignacio de las Casas, jesuita y morisco»: Shara al-Andalus 14-15 (19971998) 317-339.

— «Jesuitas y moriscos» (comentario al "Segundo remedio" de Ignacio de las Casas). Travaux et Documents Hispaniques 3 (2012) 5-15.

Hagerty, M. J., Los plúmbeos del Sacromonte. Madrid: Nacional, 1980.

La Abadía del Sacromonte. Exposición artístico-documental. Estudio sobre su significación y orígenes. Granada: Universidad, 1974.

Martínez Medina, F. J., Cristianos y musulmanes en la Granada del XVI, una ciudad intercultural. Granada: Facultad de Teología, 2016.

— «Los hallazgos del sacromonte a la luz de la Historia de la Iglesia y de la Teología católica», Al-Qantara 23 (2002) 437-475.

Medina, F. B., «Casas, Ignacio de las»: Diccionario Histórico de la Compañía de Jesús (O’Neill, C. E. y Domínguez, J. M. a dirs.). Madrid: Universidad Pontificia Comillas, 2001, 687-688.

— «Compañía de Jesús e islam en España (siglos XVI-XVII)». Archivo Teológico Granadino 80 (2017) 173-187.

— «La Compañía de Jesús y la minoría morisca (1545-1614)». Archivum Historicum Societatis Iesu 113 (1988) 3-136.

Ramos LóPez, J. De, El Sacro-monte de Granada. Madrid: Imprenta de Fortanet, 1883.

Royo Campos, Z., Reliquias Martiriales y Escudo del Sacro-monte. Granada: Abadía del Sacro-monte, 1960.

Royo Campos, Z., Reliquias martiriales y escudo del Sacro-monte. [Ed. Facsímil. Estudio preliminar por M. L. LÓPEZ y G. MuÑoz]. Granada: Universidad, 1994. 


\section{TRANSCRIPCIÓN}

Para la edición de los documentos se han tenido en cuenta las normas de la Comisión Internacional de Diplomática. Como regla general se respeta la grafía del texto en todos los casos. Nos obstante, se significan los siguientes criterios:

a) Las abreviaturas en la medida de lo posible se desarrollan.

b) Las líneas se separan por una barra oblicua y los finales de folio por dos (//), poniendo el número de folio/hoja y si es recto o vuelta con números en superíndice.

c) Se ha respetado el uso indiferenciado que se hace de la $u, v$ y $b$, ya que no afecta a la comprensión de los textos.

d) Delante de la $p$ y $b$ se respeta tanto la $n$ como la $m$.

e) Se respetan las dobles "s" y las mayúsculas.

f) Se ha respetado el uso indiferenciado de la $y$ e $i$, pues no afecta a la comprensión.

g) Las letras o palabras añadidas para la mejor comprensión del texto se encuentran entre corchetes ([ ]).

Biblioteca Histórica de la Universidad de Valencia. Ms. 637/7. Carta al cardenal Roberto Belarmino y al cardenal César Baronio; información para el papa Paulo $V$ de las láminas, libros, pergamino y reliquias encontrados en Granada entre los años 1588 hasta 1598 por el P. Ignacio de las Casas.

\section{[Carta al cardenal Roberto Belarmino]}

Al Ilustrísimo y Reverendísimo Se- / ñor Roberto Belarmino cardenal / de la Santa Yglessia de Roma. /

No será necesario Ilustrímio y Reverendísimo Señor mío / darme a conocer a Vuestra Señoría Ilustrísima ${ }^{21}$ que pienso se / acordará luego de mi así por haberme / conocido, ay en el Colegio Romano tanto / tiempo, y [h]aber sido discípulo V.S.I. y / singular por la lengua Arábiga como / por saber V.S.I. que fue a Jerusalén con / el padre Leonardo San Ángelo en Compa- / ñía del obispo de Sidonia, Criado que fue / del Ilustrísimo Santa Severina, el haber

\footnotetext{
${ }^{21}$ En este caso vamos a respetar la abreviatura V.S.I., habiendo desarrollado esta primera para su mejor comprensión posterior.
} 
/ sabido esta lengua Arábiga que digo medi- / anamente [sic] me [h]a dado siempre ocasión de $/ /^{\text {iv }}$ dessear con[?] de haser [sic] algún fructo según / el instituto de la Compañía en los ánimos / de los de esta lengua y emparticular [sic] de / los que desta ay en esto reynos de España / que son más de la tercera parte dellos, y asi / luego que boluí a estas partes de la misión / de Oriente, y del [h] aber estado en essa Peniten- / ciaría de San Pedro, Procuré acabar mis es- / tudios de Teología solo para emplearme / todo en esto, conocimiento que [h]an destituydas / están estas almas del socorro que se les de- / be dar estando ellas en el riñón de la Yglesia / y tenidos por hijos della. Están lastimoso / el estado desta gente y por ella el de toda / España que tengo por cierto, que entendido / de V.S.I. tomara con veras de ayudar / a su remedio, porque como verá que es ma- / yor y más lastimosso, que todas las here- / gias Ultramaringo $^{22}$ y más digno de ser re- / mediado por vía de los nuestros que el //2r acudir tantos de nuestra Compañía a las dos / Indias, tenía hecha una información desto / por orden del Ilustrísimo Gimnassio para el Papa / Clemente de F.M. la qual embié [sic] a nuestro Padre / General y su paternidad después de vista la / mandó dar al doctor Francisco de Quesada / que esta en esa corte por su Magestad para / los negocios desta gente y es oy refunda- / rio apostólico utriusque signaturea, para que / con tiempo y comodidad la communica- / se a su Santidad. Se que lo oyrá mejor nuestro Señor / de V.S.I. la mande pedir y ver que / al dicho doctor escribo la de a V.S.I. y aunque / embio con ésta las conclusiones que me [h]an / parecido más esenciales de todo y más cier- / tas ymporta el ver aquella información / que dice más en particular. Lo que [h] ay en esto es / con ocasión de saber lo que he dicho desta len- $/ /^{2 v}$ gua Arabiga permitió el Señor que yendo a / Granada que es donde yo nací viesse por orden / del Arçobispo de aquella Ciudad algunos de / los libros que allaron [sic] cerca della, escritos em [sic] / Plomo y hauiendo topado doctrina conde- / nada por la Santa Yglesia Romana y otras / que derogan a su fidelidad y verdad, y otras / Peligrosas y dañosas para estos Reynos y ha- / viendo dicho lo que debía con el Arçobispo, y viendo que no me oya, di quenta a la Ynquisición / y después a la Santidad de Papa Clemente de F.M. / el qual por un bulto particular mando al / Arçobispo entregasse los libros al $S^{\text {to }}$ Nunçio / y Cardenal Genasio. Pero por muerte del pon- / tífice se [h]a quedado esto así hsta a[h] ora. Auía por orden y mandato del mismo Ilustrísimo / Genasio echo otra información de esto para el / Pontífice antes de la muerte. Pero por los Negocios suçedidos asta aquí a Nuestro Santísimo Padre / Paulo V no me [h]a parecido embiarlas tuve si- $/ / \beta r$ empre intento de embiar estos Papeles a Vuestra Señoría / Ilustrísima porque confio sin duda que como / tan zeloso de la honra de (?)

\footnotetext{
${ }^{22}$ En el manuscrito de Madrid aparece transcrita esta palabra como «Ultramontanas».
} 
bien de la / Yglesia y de los Próximo instara con su $\mathrm{S}^{\mathrm{do}}$ / para que procure el remedio en todo pues / hallara que estas dos cosas están tanto (?) (?) / (?) que el remedio de la una pende de la otra/ y aunque toca tanto al Rey Filipe y a sus / Reynos quanto Vuestra Ilustrísima es solo de la silla / Apostólica el procurar el Remedio com- / bicente y si pareciere a Vuestra Ilustrísima dar parte de / todo al Ilustrísimo Baronio gustare por el mucho / zelo que su señoría tiene y erudición de / cosas pasadas en el obre viense que Vuestra Ilustrísima / gustara de ver estas informaciones y más la / de los libros y se maravillara que los Prela- / dos y doctores destos Reynos [h]ayan pasado y pa- / sen por cosas semejantes. //3v

\section{[Carta al cardenal César Baronio]}

Al Ilustrísimo y Reverendísimo Señor Cardenal César Baronio. / Ignacio de las Casas de la Compañía de Jesús. /

Sabiendo Ilustrísimo y Reverendísimo Señor el amor que Vuestra Ilustrísima / tiene a la Compañía y a todos los hijos della y quan / diligente inquisidor dellas verdades que impor- / tan al bien de la Yglesia y quan zelosso del bien / de las almas, me apareçido dar parte a Vuestra Ilustrísima / de dos cosas que importan al bien de la Yglesia / no solamente destos Reynos de España sino de / toda la universal. El uno es de los descendi- / entes de ma[h] ometanos que a 100 años que se / bautizaron en estas partes cuyo estado es digno de / lágrimas como Vuestra Ilustrísima verá, y el otro de cier- / tos libros escritos en plomo en lengua y ca- / racteres arábigos con nombre y título de que / algunos dellos fueron dictados por la Virgen / Santísima y por el Glorioso Apóstol Santiago / del qual se dice en uno que llegando a unas quebas $^{23}$ [sic] / que están cerca de la Ciudad de Granada estuvo / en ellas //4r más de quarenta días, dictó este libro. Esta todo tratado de tal suerte con lo de los Moris- / cos que allen [sic] de que les es pernisiossimo para / su conversión, es peligrossisimo a los mismos / Reynos y se a da asi a los curiosos Hereges que / oy ay de perturbar la paz dela Yglesia. Em- / bio todos los papeles que sobre ambas cosas tengo / escritas al Ilustrísimo y Reverendísimo Cardenal Roberto Be- / larmino para que comunicados con Vuestra Señoría Ilustrísima / traten con su Santidad del Remedio combiniente / a estas almas en particular y del bien de la / Yglesia. Mi intento y zelo no es otro que seruir- / la como fiel hijo suyo, y emplearme mientras vi- / va en ayudar a esta conversión

${ }^{23}$ Cuevas. 
como hijo de / la Compañía. No tengo que en carecer a Vuestra Señoría Ilustrísima / la brevedad en procurar con su Santidad los remedios / porque se cierto que el Señor cuyo es este negoçio / dará a Vuestra Señoría Ilustrísima y al Ilustrísimo Cardenal Belarmi- / nio su copiosso espíritu para efectuar lo que / conviene en negocios tan grandes. $/ /^{4 \mathrm{v}}$

\section{[Información enviada al papa Paulo V en 1607]}

Información de las láminas, libros / y lo demás hallado en la Ciudad de Granada / y cerca della, el año [al margen: 1588 asta] de 1598, da / a nuestro Santísimo Padre Paulo, Papa / quinto. Por Ignacio de las [texto tachado] / Casas, de la Compañía de Jesús / este Año de 1607. /

Siendo en estos Reynos Nuncio y Colec- / tor Apostólico el Ylustrísimo carde- / nal Genasio, entendió [al margen: como io avía dicho] a la interpreta/ ción de çiertros libros de plomo aravigos / que años a se hallaron en un monte cer- / ca de la Ciudad de Granada y juzgándose / negocio que toca de ueras a la Yglesia y a e- / sa Santa Silla me embió a llamar; lle- / gado a su presencia me mandó que escriuiesse / mi particular información de todo lo que //5r entendía de los libros y su doctrina y aña- / diesse mi sentir en ello. Mandome inmediatamente / que hiçiese otra información a cerca del esta- / do de los Moriscos que ay en estos Reynos pa- / reçiendoles lo que es ciertos que estas dos cosas / tienen tal travaçón entre sí que se puede / tener por una y tan grande a la silla / Apostólica y a estos Reynos quanto lo que / de ser otra para embiarlas al Pontífice ante- / cesores de Vuestra Paternidad y luz para ser negoçio tan gran- / de que quería que yo acompañase a su Señoría / Ilustrísima a esa corte para dar personal / quenta a la F. M. del Papa Clemente / octauo el qual auia poco antes a mandar al / Arçobispo de Granada por un buleto des- / pachado en esta Corte en san Pedro, a 15 de / Noviembre de 1603, entregase los libros / Arauigos hallados al Nuncio, por combe- / nir ansi a esa Silla Apostólica. Lleuó el Señor $/ /^{5 v}$ para si, en este medio, al pontífice y el Ilustrísimo / Nunçio hubo de ir a essa Corte dexando to- / do esto en el estado que he dicho, tenía casi a- / cavados estos trauaxos antes de su parti- / da por estar ausente de la Corte no pude en- / tregarselos y después aca auiendo Dios da- / do a la santa Yglesia a Vuestra Paternidad por su Bicario / no [h]a tenido ocasión de presentarlos a sus San- / tísimos pues [h]asta este punto [h]agolo con el re- / dimiento que deuo y para ser mejor y más / cauilmente entendido [h]aré de estas cosas tratadas / en Granada. Tres tratados, en el primero daré relación de todo lo hallado, en el segundo pondré las contradicciones que / contra ello 
a hauido, el último será de / la doctrina que contiene añadiendo don- / de me parece combenir alguna exposici- / ón y declaración. /

De los Moriscos embie días a a [sic] esa corte / mi sentir y por ser todo de Santa ympor- //6r tancia [quanta verá] ${ }^{24}$ Vuestra Santidad y pedir el remedio conveniente y no poder / escriuirse tan en breue me(?) fácil / para tener Vuestra Santidad la noticia decido embiarlo / todo a los Illustrísimos cardenales Belarminio y Baronio los quales con su celo y letras / referirán a Vuestra Santidad lo que en ello ay y suplica- / ran la breuedad del remedio combeni- / ente cuyos santísimos pies humildemente / beso y cuya bendición deseo alcançar. /

Tratado $1^{\circ} / / 6 \mathrm{v}$

Tratado primero. /

Relación de todo lo hallado en / Granada y cerca de ella. /

Capítulo $1^{\circ}$. De la Caxa y lo que / en ella auia. /

El año de 1588 a 18 de Março derri- / bandosse una torre vieja que era campa- / nario de la iglesia mayor antigua de Gra- / nada que en tiempo de moros fue mezquita / y oy es sagrario a Parroquia de la iglesia / mayor y de aquella torre llamauan los al- / muadane ${ }^{25}$ a las horas de sus ceremonias se- / gun su secta. Se alló [sic] entre las piedras y ma- / teria es que auían caydo una caxa de plo- / mo de cerca de una quarta de largo y una más / de quatro dedos de alto con su tapadera de / plomo embetunada toda ella de dentro y fuera, $/ / /^{\mathrm{r}}$ en la qual estaua un pergamino, un hu- / eso de poco menos de una sesma y un pedaço / de lienço algo grueso casi triangulo.

\section{Del Pergamino. /}

Es el pergamino de una piel delicadissi- / ma, y esta escrito en tres lenguas: Aráuiga, / Castellana y latina, y a los márgenes y en- / tres renglones ay letras griegas y latinas / correspondientes como cotas. A la mano / yzquierda deste pergamino en lo alto del / están cinco cruces a esta forma [dibujo] y jun-

${ }^{24}$ En el original no se puede leer lo que pone utilizamos el manuscrito de Madrid para completarlo (ms. 7187, fol. 67v.)

${ }^{25} \mathrm{Al}$ margen: «Almudanes son / ciertos como / sacritanes que / donde estas torres / de las mezquitas / dan uoçes [llama-] / do a gritos a sus çe- / remonias. Lla- / manse Almuda- / nes porque para $\mathrm{dar} /$ los gritos que dan / se meten los de- / dos [en las orejas]». 
/ to a ellas cinco renglones está es- / crita en la misma letra y lengua aráuiga / una larga escritura de cantidad de renglo- / nes. Deuaxo desto escrito en aráuigo ay [tachado] hechas / varias líneas o rayas y cruzadas otras / por ellas de suerte que hacen barias casillas / pequeñas a modo de ajedrez en cada ca- $/ / \mathrm{v}$ silla ay una letra castellana o latina algo / bastarda, al modo de este tiempo. Las primeras / de tinta negra, y la segunda de colorada / y se leen continuando las letras negras con las / coloradas no hacen sentencia ni ddiçen nada. / Pero leyéndolas negras por si y acauadas ellas / leyéndolas coloradas hacen el romançe que / pondré más abaxo. /

Siguense, después de los escrito con las letras / nuestras, otros renglones en Aráuigo, susodichos / también en casillas como las dichas, pero en / cada casilla ay una palabra aráuiga, y no le- / tra sola, y esta escrita esta palabra, al pareçer con / precissa y alguna dicciones [tachado] / [tachado], medio borradas, y son también co- / loradas y negras. /

Después de lo escrito en aquellas casillas, se siguen / algunos renglones en la misma letra y len- / gua, y poco más abaxo, otro pedaço de escritura / también en Aráuigo y al margen de esto //8r están unos renglones en la misma letra / como nota o cota. /

Debaxo desto último escrito [tachado] en aráui- / go esta una como firma que con letra Aráuiga / dice así Cecilio obispo Granatensis. /

$\mathrm{Al}$ un lado [entre renglones: del fin] del pergamino esta en latín en letra / francessa, como la que ahora se hussa, lo siguiente: /

Relatio Patricii Sacerdotis. /

Serbus dei recilius episcopus Granatensis cum / in Hiberia eset, et cum videret dierum suorum / finem oculte mihi dixit, se abere procerto suum / Martyrium et apropinquare, et ut pote qui me / in Deo amuit thesaurum suarum reliquiarum / mihi comendauit, et me admonuit, ut oculte / haberera et in loco locarem ut impotentiam / maurorum nunquam venerit afirmans ese / thesaurum salutis ac sei entia certa et pluri- / mum laborase et iterfecise terra mariam et / debere ese in oculto loco donee Deus vellet / illum manifestare, et egomelius quam in telle- / xi in hoc clausi, ubi iacel, Deum rogans ut e / um obseruit. Reliquiam qua nunc hic ia- / cent sunt. /

Profetia diui Joannis euangeliste in confinem / mundi. / 
Medius pannus quo Virgo Maria abstersit ab oculis lacrimas impasione filii sui Sacrati:

Os diui esteuan primi martiris. /

Deo gracias. /

Todo esto contiene el pergamino. /

Capítulo $2^{\circ}$. Esposición de lo contenido [tachado] / en el pergamino sacada del capítulo 13 de los / discursos que imprimió el doctor Madera, / deste Monte de Granada. /

El título en Aráuigo que esta junto a las / cruçes dice ser una profecía del Euangelis- / ta san Joan que trata de la consumación // $/$ r del mundo conforme a lo que aquel Apóstol pre- / dicaua. El Aráuigo siguiente es una / Narraçión de cómo san Cecilio hiço un biaxe / a Jerusalén, por uisitar y venerar los lu- / gares Santos por su deuoción y para ganar / el mérito que de uisitarlos se sacaua. De vuelta / se uino por Atenas donde ya se profesaua la The- / logía puesta en orden y método de sciencia / conforme al arte de los Griegos. Añade que / de la nauegación se le empeñaron los ojos de / aquella ciudad se confesó por su orden y recibió / el cuerpo de Cristo nuestro Señor y acauado el sacrifi- / cio de la misa sacó el Prelado una grande re- / liquia que era una toca o paño de la Virgen / María con la qual hauía enjugado las lagri- / mas mezcladas [sobre la «e» un 3$]^{26}$ con sangre que derramó al ti- / empo que asistió en la pasión de su hijo y que / en poniéndosela le fue luego restituyda la / uista, y pudo leer esta profeçia que le mostró $/ /^{9 \mathrm{v}}$ también el Prelado y que le dio desseo de / verla traducida en lengua española como lo / hiço. Escriuió también un comento de ella en / Aráuigo sin que por ser traduçion se corrompiese / la propiedad del griego en que san Dionisio / la auía trasladado del Hebreo en que / San Juan la escriuió y juntamente con grandes / ruegos e importunaión alcançó de el la mitad / de la toca o paño dicho, y lo puso todo junto, lo qual / se descubriría quando Dios fuesse seruido para / que los Príncipes en ello sean auisados. I

Sigue luego la profecía en español con letras des- / te tiempo coloradas y negras, destribuidas en / escaques, y leidas las negras por si primero y las / coloradas luego por si [h]acen el Romançe y narra- / ción siguiente: /

\footnotetext{
${ }^{26} \mathrm{Al}$ margen: «3. / Dise Madera que / este obispo o pre- / lado era san / Dionisio».

En el manuscrito de Madrid, después de transcribir la nota al margen añade debajo: «engañose en esto el / Señor Madera y con / fiera después de con- / siderado». (fol. 70v).
} 
La edad de la luz y acomençada por el Maestro / y con su Passión Redimida con dolor del cuerpo / y os Profetas pasados que alumbrados de la terce- / ra Persona esperaron su venida. Del mundo $/ /{ }^{10 \mathrm{r}}$ el acauamiento quiero contar por boca deste Ma- / estro en la misericordia preferido. A los seis siglos / cumplidos de su aduenimiento por pecados graues / en el mundo, que cometidos serán tinieblas, se / leuantarán muy escuras en las Orientales par- / tes, y a las Occidentales se estenderán por minis- / tros furiosos que en ellas serán criados, con que / la luz de nuestro sol se (?)prara y el templo / del Maestro y sufre graues persecuciones pa- / decerán, y los quince siglos cumplidos por los / pertinaces coraçones endurecidos. Segundas ti- / nieblas se leuantarán en las partes de Aquilón / y de ellas un dragón saldrá que por su boca arro- / jará simiente que sembrará la fee diuidirá / en sectas, y con la otra juntada el mundo [tachado] / [tachado] ocuparán. De las orientales partes sal- / drán los tres enemigos su malicia augmentando / y por su maestro la sensualidad traerán y con / lepra [tachado] nunca vista el mundo se infi- / çionará, la luz en parte diminuta de la tie- / rra se retirará a donde con naufragios sustenta / da (?) en el abrigo de la coluna de su piedra. Con / estas señales prodixiossas y otras que el Cielo mos- / trará, el genero humano será amenaçado y en es- / [pe]cial el sacerdocio y anunçiado el Anticristo que / será breue su venida con que esta profecía se cum- / plirá y el Juycio final se acercará quando se / manifieste al mundo esta verdad, verdad, ver- / dad [sic] cumplida del medio día saldrá el Juez de / la verdad quando le plaçerá. /

Escriue luego en Aráuigo el comento que hauía pro- / metido en escaques, como está dicho, condiciones ne- / gras y coloradas, y dice este autor que declara que / la uenida de aquel Profeta falso será después del / Año de 600 y que los secuaces de sus errores se es- / tenderán donde el oriente al poniente, y que la / venida del otro dragón endemoniado de la parte / del setemtrion será después del Año de 1500 y / que no introducirá muchos errores con la fee de la / Yglesia a su diuidirá en sectas concurriendo en / el mismo tiempo las enfermedades nuevas que / se denuncian y grandes Pecados. $/ /{ }^{11 \mathrm{r}}$ Concluydo el comento buelue a su narración / en Aráuigo, y dice que esto es lo que entiende de- / lla conformándose con la doctrina euangélica. / Cierra su escriptura con poner las palabras del / euangelio de san Joan en Aráuigo hasta aque- / llas Palabras lleno de gracia y verdad. Está / puesta luego en latín la relación del sacerdote / Patricio, y al fin la firma de Cecilio obispo como sea / dicho y no ay señal de Año ni numero o en todo el pergamino. /

Hubo por este tiempo varias interpretaciones de / lo que estaua en Aráuigo del pergamino y barias / dubdas de hombres sobre las quales mouieron al / 
Prelado, que era entonces don Joan Mendez de / Saluatierra ${ }^{27}$, arrecoxer [sic] esta Caxa con lo que en / ella hauía sin hauer otra nouedad alguna, / ni la hubo en esto asta el año de 1595. /

Capítulo 3. De las láminas, cubiertas de los libros, y libros que se halla- / ron cerca de Granada. //11v

Saliendo de Granada por la puerta nueva de / Guadix, que algunos llaman del Sol, y lleuando / a mano derecha el Río Darro que corre de oriente a / poniente por un profundo valle de huertas / y a la mano yzquierda muchos y barios montes y que- / brados en los quales ay barias quebas, en una de / ellas que está como quatrocientos pasos de la Ciudad / se dice que cauando unos hombres en una queba / que está en el por hallar un tesoro ${ }^{28}$. Hallaron u- / na lámina de plomo el año de 1595 por / el mes de Março, la qual uino a manos del Pre- / lado, y leyda viendo que decía que auía allí un / cuerpo de santo hiço cauar, y en barios días y me- / ses asta el año de 1599, se hallaron en aquella / cueva y [o]tras conuecinas las láminas y libros que / pone. /

Son láminas unas plan- / chas de plomo de más de una cuarta de largo / la letra que tienen es al parecer hecha a golpes con / algún hierro algo voto, y el que las escriuió, que / al pareçer fue uno en todas, no sauía mucho de es- / criuir así ni mucho latín, después de cada pa- / labra ay dos puntos ${ }^{29}$ y la forma es casi la siguiente. //2r

\section{[Línea escrita en caracteres a penas legibles] $]^{30} /$}

Las cubiertas de los libros son también planchas / de Plomo no tan largas como las cubiertas pero / más anchas y las que tienen algo escrito es con / la

${ }^{27}$ En el manuscrito de Madrid pone al margen: «Antes don Juan Mendez / arzobispo, formó proceso / (?) su mandado al D. / Bar(?) su prouisión lo ay / está con los demás autos / pero (?) por lo so(?) dos / meses bino el arzobispo / dar (?) la arca estas / reliquias».

${ }^{28}$ En el manuscrito de Madrid en el margen pone una anotación que se lee con bastante dificultad. Pone: «Maliciosamente re- / fiere el hecho dimi- / nuto, es así que auia / cueuas en el monte pues / se descubrieron, pero / no las auia descubiertas / ni me (?) (?) / (?) allí las venir a aui- / do hasta que hallaron y / estauan todas (?) la / nadas con señas ciertas / y cuida(?) de grandisi- / ma antigüedad, y esta / mucho más distante de / la ciudad (?) dize y / el hallarse fue muy aca- / so».

${ }^{29}$ En el manuscrito de Madrid, pone al margen: «No de cada pala- / bra sino de algu- / nas».

${ }^{30}$ El manuscrito de Madrid deja un espacio en blanco en donde tendría que estar transcritos dichos caracteres. Además, en nuestro manuscrito aparece una nota marginal que parece una traducción al latín del texto en cuestión, pero del que solo se puede leer con claridad la última palabra: diui. 
letra y forma de las láminas de las quales / pongo aquí lo que anda impreso en un papel / y en el libro del doctor Madera. /

La Primera que se halló dice, corpus cost(?)m / diui Misitonis Martiris Pasuses sub Neronis / Potentatu. [Al margen: 22 de Março]. /

La segunda dice: /

Anno secundo Neronis imperii Martirii calen- / dis pasus fuit martirium $<+>$ [al margen: + / hoc loco Illipu- / litano]: electus at hunc effe- / ctum sanctus Hiscius Apostoli Jacobi discipulus / cum suis discipulis: Pane(?)rio: Jurilo: Maro- / nio: Centulio: per médium ignem inquo viuiambuti fuerunt: eternam vitam pesentibus transivere: vt lapides in calcem combersi fuerunt: corum Pulbis in $<$ h>iuis sacri montis caber- / nis incent qui ut ratio postulat in corum me- / moriam venertatur. //2v

\section{La tercera dice /}

Anno secumdo Heronis imperii calendis Apri- / lis ${ }^{31}$ posus es Martyrium in hoc locos ilipulit / [espacio en blanco] ${ }^{32}$ us Thesifon dictus prius quam con/ vertentur: Abenatar: diui Jacobi Apostoli disci- / pulus vir literis et sanctitate preditus: plumbi / tabulis scriptit librum <illis $>$ fundamentum ecclesie / apelatum: et simul pasi sunt: sui discipuli dibus / Maximinus: Luparius: quórum Pulbis et / liber sunt cum pulcribus diuorum Martyrii / in huius sacri montis [espacio en blanco] cauernis in corum memoriam veneratur. /

La quarta dice. /

${ }^{33}$ Anni secundo neronis imperii calendis febru- / aris: Pasu est martyrium in hoc [espacio en blanco] tano / diuus Cecilius, santi Jacobi discipulus, vir li- / teris singuis et santitate preditus Profecias / diui Joannis Apostoli comentauit, que sunt po- / site cum alliis reliquiis in sublimi parte in- $/ /{ }^{13 r}$ hauitabilis turris Turpiane secut dixerunt / mihi sus discipuli dibus septentrius, et Patri- / tius que cum illo pasi sunt, quorunt pulueres / iacent in vices sacrimonteis couernis inquorum / memoriam veneratur. /

\footnotetext{
${ }^{31}$ Al margen: «10 de abril».

${ }^{32} \mathrm{Al}$ margen: «Lo blanco está car- / comido en las láminas».

${ }^{33} \mathrm{Al}$ margen: «a 30 de abril».
} 
La primara tapa dice. /

Liber fundamentum ecclesiae salomonis caracteribus scriptur ${ }^{34}$. /

La segunda dice. /

Liber de esencia dei: quem dibus The[si]fon, $\mathrm{A}^{35}$ - / postoli Jacobi discipulis in sua naturali lingua / Arabica Salomonis caracteribus, scripsit et a- / lium fundamentum ecclesie apelantum quium / huius sacrimontis cauernis yaut [sic] deus a Ne- / rone imperatore os duos libros liberet imposu / et finem hic: in suisoperibus seribens miracula / et vite inte [espacio en blanco] itatem sui magistri [espacio en blanco] / ui [espacio en blanco] in huius sacrimontis [espacio en blanco] ca [espacio en blanco] est. /

Libros que se hallaron. /

1. Fundamentii ecclesiae, este se alló a 22 de abril de 1595. //13v

2. De essentia dei. Este se halló a 29 del dicho mes y año. /

3. Tercero y quarto son catecismos. /

5. Misa de los Apóstoles. /

6. Oración de Santiago. /

7. Primera parte de Prouidencia. /

8. Excelencias de la fee estos no se quando ni como se allaron / ni porque $\operatorname{orden}^{36} .1$

Estando yo en Granada el año de 1597 desde / el mes de Junio asta el de Abril del año sigui- / ente se allaron. /

9. Segunda Parte de Prouidentia con el qual / están juntos tres tratados: Primero de An- / geles, segundo de Anulo Salomonis. Tercero / de Beata Patria et inferno.

\footnotetext{
${ }^{34}$ Al margen: «a 22 de Abril».

${ }^{35}$ Al margen: «a 29 de Abril».

${ }^{36}$ En el manuscrito de Madrid pone al margen: «No ay libro en este / título».
} 
10. de la Historia de la uerdad del euangelio glo- / rioso. /

\section{Del ensalçamiento de la Virgen a los altos Secre- / tos de Dios ${ }^{37}$. /}

12. Es un libro illegible que no ay quien entienda / que letra es ni lo que dice, estos tres libros //14r últimos estauan en una piedra de poco más de / una quarta en largo y poco más de ocho dedos en an- / cho si uien me acuerdo porque a ya años que la uí. / En esta estauan tres concauidades redondas hechas / con compás redondas bien talladas y en ellas esta- / uan los tres libros dichos, tenía por cubierta otra / piedra también ajustada con la dicha que de re- / pente se juzgara ser una el illigible estaba (?). / Son todos estos libros de delicadas ojas de plomo / redondas al tamaño de ostias no muy grandes / aunque ay algunas meyores que otras solo / una es ovado [sic] pequeño que contiene la ora- / ción que dicen de Santiago. /

La letra es de dos formas o manos bien diferen- / tes ${ }^{38}$ galanemente exarada en el Plomo al modo / que escriuen los arauigos en regla y planchas de / las quales e uisto muchas y se me queda esta cortada / con buril en la forma y modo siguiente y están / por ambas partes escritas. /

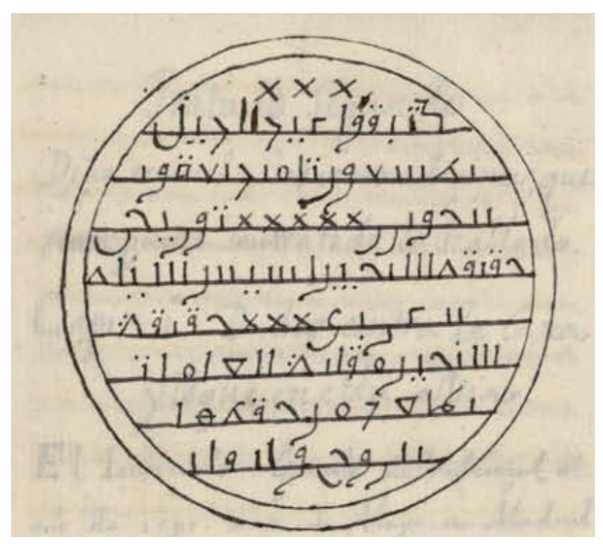

Lo que está escrito deste círculo aunque es de / los libros no es con concierto $^{39}$. El título del sello / [tachado: del sello] de auajo es del illegible que era en / esta forma el que tenía en la primera Hora. //15r

\footnotetext{
${ }^{37}$ En el manuscrito de Madrid hay una anotación al margen que no se puede leer bien.

${ }^{38}$ En el manuscrito de Madrid hay dos anotaciones al margen que no se pueden leer bien.

${ }^{39}$ Al margen en el manuscrito de Madrid: «porque no los tenía / no los (?) saca- / (?) (?)» (fol.
} 76r). 


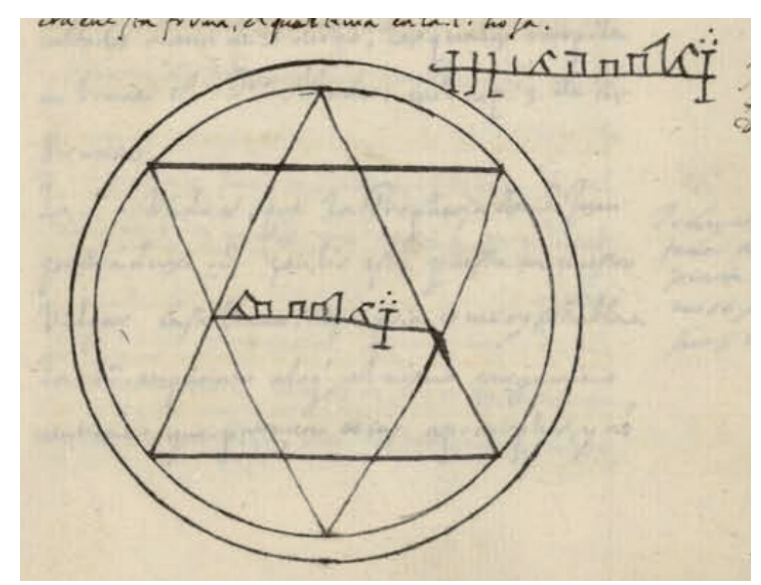

Tratado segundo. /

Dicense en él las contradiciones que se an [sic]puesto contra todo lo hallado. /

Capítulo $1^{\circ}$. Dudas contra la Caxa y lo / que en ella hauía. /

El licenciado Gonçalo de Balcarçel el año / de 1595 a 18 de mayo en Madrid presentó / una petición en Consejo Real y con ello un largo / discurso diligentemente estudiado donde pro- / pone muchas dudas y dificultades a cerca / de lo dicho las quales recopila en breue el / doctor Madera en el capítulo 3 de sus discurso. I

1. La Primera duda es que la Profecía de san / Joan que traduxo san Cecilio está puesta en año / vulgar castellano tam [sic] propio como oy se habla ${ }^{40}$. /

2. La Segunda en quanto a lo que el mismo Perga- / mino contiene que parecen cosas apócrifas / y no conformes a lo que el mismo Apocalipsis //16r escriue en su Apocalipsis. /

3. La Tercera es hallarse en el pergamino escrito / el principio del euangelio de san Joan y puesto / antes del Año segundo de Nerón pareçiendo / por muchos autores Graues que san Joan escri- / uió mucho más tarde su euangelio. I

${ }^{40} \mathrm{Al}$ margen en el manuscrito de Madrid: «Todas estas dificul- / tades (?) res- / puesta bastante / no se pone aquí / (?)» (fol. 76r). 
4. La quarta que se firma san Cecilio obispo Grana- / tense no auiendo memoria de Granada por a- / quellos tiempos ni de tal título de obispado / en toda aquella Antigüedad. /

5. La quinta que se hallasse en la Caxa Reliquia / de san Esteuan cuyo cuerpo no se descubrió has- / ta tantos años después en tiempo del emperador Honorio. $/$

6. La Sexta que se hace mención en el pergamino de / los moros que tantos años después ocuparon España. /

7. La Setima [sic] que parece la narración de san [texto tachado] Ceçilio / en muchas cosas fabulossa y commenticia por / no se hallar mención della en otros autores y / tener algunas muy dificultossas de ponderar / en lo que sauemos ansi en decir que escriuió //16v San Joan la profecía en lengua Hebrea puesto / de lo que escriuió este euangelista fue en Griego / como en afirmar que la traduxo san Dionissio / en griego y que este santo supiesse Hebreo en ha- / cer mención de lugares santos de Jerusalén / del estudio de Atenas en letras sagradas y de / Peregrinaciones. /

8. La octaua que el estilo no parece de san Joan ni a- / y [sic] memoria en los autores de aquellos tiempos / de tal profecía ni de que san Joan fuese profeta / sino en el Apocalipsis y que ay algunas pala- / bras que no parecen combenientes a lo que en- / tonçes se profesaua como es llamar al mismo / euangelista diuo y santo en su vida y con / vocablo que aun no le auían reciuido los / cristianos por ser muy de superstición y gentilica. /

9. La nona que pues los Profecías se escriuen para / auiso de la posteridad y esta su fuerça en preuenir / lo futuro no era cmbeniente que se escondiese / pudiéndola entregar san Cecilio a otros cristianos/ que la publicaran. //17r

10. La décima que no parece se husara [sic] entonces tan / generalmente el Arauigo, y a lo menos en / España y África no podía ser conocido hasta que / vino a ellos con los Maometanos que la conquistaron. /

11. La undécima que aquella manera de escre- / uir en escaques parece cossa de ficció y no deçen- / te a tan grande santo como san Cecilio y que la / Palabra sacerdos y el estar escrito en pergami- / no y el nombre de la torre Turpiana no pa- / reçe de aquellos tiempos. / 
Capítulo 2. Otras dudas que proponen otros / sobre lo mismo. /

1. Primera como es posible que estando esta Caxa in- / sublime pare inabitabilis turris Turpiana. / La qual palabra en habitabelis interpreta / Madera capítulo 12 maçiza y sin aposentos / quando la pusieron los $\mathrm{Ma}<\mathrm{h}>$ ometanos por su / Torre de llamar ${ }^{41}$ (que husan [sic] ellos con qua- / tro ventanas a los quatro vientos), estaua //17v desta manera acomodada? y si era Maciça y / sin aposentos como el mismo autor dice como / después hauitaron en ella los compañeros con sus / mujeres e hijos comouimos en nuestros días? Y / como pusieron en ella los cristianos en sublime / parte y tan [texto tachado] tas y tan grandes campanas? Co- / mo para asentar las mismas derriuaron ni to- / caron donde estaua la Caxa? Difícil es <de $>$ creer / que hauiendo derribado tanto los moros y / los cristianos para sus conmodidades desta / sublime parte no topasen con ella; por lo qual se sospecha con Raçon que no cayó del alto si- / no que fuese puesta entre las ruynas en el / suelo donde se halló sin berla [sic] caer. /

2. Segunda, la astucia humana saue haçer / las cosas que parezcan antiguas aunque sean / modernas y se tema que el pergamino lo es, a- / unque parece la piel desconocida y apolillada / por su antigüedad ${ }^{42}$, y la Raçon es de sospechar esto / son graves porque la letra Arauiga de él se / ue ser moderna la que llaman oy los scrito- $/ /{ }^{18 r}$ res arauigos diuuania [sic] que quiere decir cance- / llaresca de la qual buscan los textos y no se ha- / lla en autores an $<\mathrm{ti}>$ guos. Yten si de la lengua / castellana que se pone en el pergamino se du- / da con quanta maior Raçon se dudará de la / forma y con mayores fundamentos de lo que / se escriue en latín que es la Relación de Pa- / tricio que es latra francessa como se husa [sic] oy en / aquel Reyno y viene en los buletos de Roma. / Todo esto da ocasión de suspechar que fueron / varios y de uarias naciones lo que compusieron / aquel pergamino. /

${ }^{41} \mathrm{Al}$ margen en el manuscrito de Madrid: «yerra en todo / por no confor- / marse (?) / la versar (?) / hecho. /

La torre sur tenía / de todo su ancho / exterior $\mathrm{m}($ ?) / diez y seis tercios / en esto entran el / grueso de las paredes y los dos / amondas de la buel- / de caracol y / escalera por (?) / arriba sea (?) / donde cabria habi- / tación o comopu- / dieron habita los cam- / paneros y su familia, es falsa. /

Las ventanas donde / estaban las campanas eran de ladrillo / y añadido aquel / edificio sobre la / torre antigua que / era de piedra y / ahora la añadiesen / los moros o la halla- / sen los camperos / los cristianos que no eran / en esto (?) e / (?) compañero...» (fol. 79r). A partir de aquí el texto no se entiende bien, queda algo borroso.

${ }^{42} \mathrm{Al}$ margen en el manuscrito de Madrid: «Confiesa que es extraordina piel la del / pergamino y lo esta- / una apolillada. Esto / no ay arte conque con-/ mo hazerlo y asi lo / an [sic] dicho los oficiales» (fol. 79r). 
[Al margen: 3] Tercera no responde al doctor Madera ${ }^{43}$ cosa / que satisfaga a lo que se dice de ser cossa indigna / de un santo tan graue como san Cecilio el auer / escrito en escaques sin verse secreto más gra- / ue que saltar una casilla, y no importando / esto al autoriçado ni a otra cossa, aprieta mu- / cho más esta duca el ver que muchas de las / dicciones del aráuigo que están escaques, / esta medio borradas y de tal suerte escritas //18v que aun copiarlas ad verbum $\mathrm{no}^{44}$ an acertado los / intérpretes como se le hizo demostración clara / al Arçobispo y él la reconoció. Yten leydas / y juntadas en barios [sic] modos hacen barios y di- / versos sentidos, pues escriuir un santo cosas / de tanta importancia como son las que an de ser / auiso y dirección para guardarnos de males / futuros y más el clero, poner las tan iligibles. / Anbiguo [sic] y dudoso su sentido y en forma y mo- / do de juguete, véase si es uso del spiritu de / uerdad en su yglesia. /

[Al margen: 4] Quarta. Si en la narración de san Cecilio en A- / ráuigo esta lo que exponen algunos era in- / térprete en la lengua husada de Aljamia, / se ve claro ser fingimiento, porque siendo lengua / natural propia del santo la Aráuiga, bien / sauía que esta palabra a Algiamia signifi- / ca lengua báruara, qualquiera otra qe / no es aráuiga y no denota más castellana, / francesa, italiana, o latina que griego o per- / siana. En Oriente llaman los maometanos [sic] $/ /{ }^{19 \mathrm{r}}$ a los Persas Aagian y a su lengua Persiana ${ }^{45} /$ Aagimia, como en España [h]an husado los á- / raues deste siglo y no antes llamar a la lengua / española Aagimia para decir báruara, y / no Aráuiga, y si hombre advertido escriuiera / aquella narración auía de añadir en lengu- / a husada del Aagiamia de España. /

Las letras griegas y latinas que están a la / margen y entre lo escrito del pergamino como / cotas, dan claro indicio que pretendieron los au- / tores del, deslumbrar los entendimientos y ha- / cerlos andar adiuinando como y con quien conierta / esto mismo Pareçe que descubre la nota que está / al margen, que interpretan ${ }^{46}$ : con coraçon puro le- / erás estas cosas sublimes y sabrás la sçiencia / soberana y sino supieres las dos lengua no / entenderás la profecía

${ }^{43} \mathrm{Al}$ margen en el manuscrito de Madrid hay un texto que se no se consigue leer bien (fol. $79 \mathrm{v}$ ).

${ }^{44}$ Como en la anotación anterior esta tampoco se puede leer bien (fol. 80r).

${ }^{45}$ En el manuscrito de Madrid dice: «La profecía esta / en lengua caste- / llano bien le lla- / mo al (?) se- / gún el uso árabe / y (?) en Espa- / ña no fue nece- / sario añadir / española o cas- / tellana» (fol. 80v).

${ }^{46}$ En el margen del manuscrito de Madrid dice: «No está esto bien inter- / pretado pero cier- / to es que el que no su- / piere latin no en- / tendería (?) la vul- / gata latina y el que / no supiere hebreo / no (?) / (?) el que lo sabe / sino solo (?) dios / o se lo declara otro» (fol. 80v). 
Griega hebrea porque /no es término de Dios obligar, variar lenguas / a saber para que nos den a entender lo necesa- / rio para nuestro uien antes prouee siempre / de ynterpretes neçesarios para esto. //19v

[Al margen: 5] Quinto. Siendo cierto que: finis profeciae est ma- / nifestatio aliuius Veritatis. [Al margen: S. Thomas 22 q. 174]. No qualquiera / sino necessaria o salten prouechossa al tiem- / po $^{47}$ que se describe y si en el no consigue su fin / y intento, ni pone remedio a males venide- / ros, aunque diga generalidades de ellos y más quando dice cosas pasadas se puede sospechar con / grandes fundamentos ser ficciones ett ${ }^{\mathrm{a}}$. /

Que prouechos si an sacado del pergamino por en- / tender por el lo que ya se sauía por la experien- / cía, que no Mahoma a tantos siglos, que / vendría Lutero a tantos que es lo esencial de / todas esta profecía? Que conuersiones auimos / uisto ${ }^{48}$ ? O esperamos ver de los sequaces destos dos / perseguidores de la Yglesia? Y en particular / de los Áraues en cuya lengua está lo esencial / de todo esto, en los quales se vee el poco fructo que a [sic] / hecho y se conocen los peligros de los deños que / resultan y resultaron en ellos y en otros. /

Lo de los tres enemigos que dice que vendrán $n^{49} /$ del poniente y $<$ lo $>$ que añade de la sensualidad $/ /^{20 \mathrm{r}}$ se ue claro, que donde el principio del mundo / an hecho [al margen: tal] guerra y la arán hasta el fin y así pare- / ce impertinencia lo que desto se dice en el pergamino. /

[Al margen: 6] Sexta. Siendo tan notable la Reliquia del medio / Paño, o toca, quandto dicen en el pergamino y sus / interpretes, notable cossa es que

${ }^{47}$ En el manuscrito de Madrid hay un texto al margen que no se puede leer bien (fol. 81r).

${ }^{48}$ En el margen del manuscrito de Madrid: «Aun no están publica- / dos ni aun recibidos / los libros, podrá ser / que resulte el fruto / que echa antici- / padamente men(?) / y muy especialmen- / te en los Árabes y / en la (?)» (fol. 81r).

${ }^{49}$ Al margen en el manuscrito de Madrid: «Quien no ve el daño / que en el mundo a hecho / el descubrimiento de / las Indias de Poniente / y lo que a acrecentado de / [no se lee bien] y / excesos y codicias y ma- / los (?) y (?) / las riquezas y re(?) / que de allí an venido / y el daño de la (?) / (?) que llega esto / a lo que no sea (?) y el hábito de verlas / se ve la(?) que no (?) / repara tanto siendo el / monje en (?)(?)posible / de san Juan Baptista / de la madre de Dios / que fue (?) que / los más santos iço / sabemos milagros / de muchas reliquias se ha- / lla poca memoria, y / esta no las haze inciertas. / Milagros a auido en / comprobación deste / paño de Nuestra Señora / que esta a (?) a / el proceso de la califi- / cación de las reli- / quías. / Pero como el mismo lo hace podría no que- / rerlas creer o [tachado] en / caso de no (?) no poderlas ne- / gar decir que fue otra la / causa de (?) lo / dize que es (?) de / desatina. Vemos de que ay prouados y ciertos milagros tales que no se pue- / den atribuir a otra causa sino a la comprobación de la verdad desto» (fol. 81v). 
no aya autor gri- / ego ni latino que aga mención del otro medio paño / que dicen quedó en Atenas en poder de san Dioni- / sio, ni aya hecho milagros quales convenía a tal / Reliquia de la madre de Dios que parece claro de- / uían hauerse hecho en descubriendosse para auto- / riçarla que es mayor que todas las demás halla- / das en el Monte y que los libros. /

Esto que digo de los milagros que parece se deuían / hauer hecho por este lienço o toca, parece que deuían / hauer sido también del hueso de san Esteuan $\mathrm{como}^{50}$ / los hubo tan insignes en la ueneración de su cuer- / po quando refieren graues autores y san Agustín / de las que traxo Paulo Oracio quando fue embiado / por este gloriosso santo a comunicar ciertas dudas / con el doctor de la Yglesia S. Gerónimo. Y si co- / mo Refiren grauer autores queles son Seuero / obispo de Menorca y Luadio Obispo de Vealero //20v Libro $1^{\circ}$, cap. 2 y lo trata el Ilustrísimo cardenal Baronio / en las anotaciones del Martirologio 3 die Augusti, / por una reliquia que el dicho Paulo Orossio / truxo en España se conuirtieron los judíos / que auía en Menorca pasando por ella con esta / reliquia por la qual abraua Dios notables / virtudes y tales que les mouió a dexar su anti- / gua ceguedad, parece que si uieramos aca por es / (?) semejantes milagros y conuersión salti / de aquellos en cuya $<$ lengua $>\mathrm{se}^{51}$ daua testimonio ser a- / quella reliquia de tan santo, nos moueremos / a no dudar de ser lo pero no hauiendo auido nin- / guna cosa destas mucho hace temer ser imben- / ciones humanas del enemigo de genero humano. /

[Al margen: 7] Séptima y última ${ }^{52}$. Sauese cierto que el a- / rauigo del pergamino assi lo dicho atrás que / esta escrito en escaques como mucho de lo de- / más no sea acertado a copiar ad verbum y me- / nos interpretar como es fácil hacer demostra- / ción con el original y copias como se puede cre- / er que diga más lo que an dicho estos interpre- $/ /^{1 \mathrm{lr}}$ tes que no otras cosas varias y contrarias. /

${ }^{50}$ En el margen del manuscrito de Madrid: «Tampoco las reliquias / hacen (?) ni / (?) / (?) / como los vemos muy / ciertos en Roma y / en otras partes / bastenos el bien de / venerarlas y el me- / rito desto en (?) / (?) de (?) / y estando estas y las / del Sacromonte de / Granada calificadas / sobre exactas diligen- / ciasde cinco años por / el prelado y concilio / prouincial y breue / apostólico y venera- / das y colocadas con / autoridad apostoli- / ca en publico gran / (?) es habla / como habla y digno / de grauisima cen- / sura» (fol 82r).

${ }^{51}$ En el margen del manuscrito de Madrid hay un texto que apenas se puede leer bien (fol. 82r).

${ }^{52}$ En el margen del manuscrito de Madrid: «Si no se a acertado a / copiar ni interpretar / como lo condena pues / de no antes saberlo que / contiene (?) conde- / narlo» (fol. 82v). 
Capítulo 3. Dudas que sean puesto / contra las láminas sa- / cadas del Doctor Madero. /

[Al margen: 1] Primera ${ }^{53}$. Siendo la quenta de los Años Alma / de la Historia, no combiene con lo que por los auto- / res se saue que el Año $2^{\circ}$ de Nerón ubo [sic] persecución y mártires. /

[Al margen: 2] Segunda ${ }^{54}$. No podían hauer uenido a España en / aquel año los discípulos de san Tiago pues los em- / biaron a ello de Roma los santos Apóstoles / Pedro y Paulo y no se juntaron en ella has- / ta el año undécimo del imperio del mismo Nerón. /

[Al margen: 3] Tercera. Ylipula ${ }^{55}$ fue en otra muy distante / que en donde se hallaron las láminas. /

[Al margen: 4] Quarta ${ }^{56}$. Si el monte era lugar diputado para / castigo de malehchores no ay seguridad que / los huesos hallados sean de santos pues po- / dían ser de otros o mezclados con ellos. //21v

[Al margen: 5] Quinta ${ }^{57}$. El nombre de Hiscio no com- / viene con el que se saue por las Hystorias deste / Sancto. El de Abenathar parece fingido y / ay duda si estos fueron discípulos de Santiago / pues autores graues y antiguos ponen otros diferentes. I

${ }^{53}$ En el margen del manuscrito de Madrid: «Lo contrario se mos- / trará con lugares de / autores buscadas y in- / criciones antiguas» (fol. 82v).

${ }^{54}$ En el margen del manuscrito de Madrid: «No los embiaron san / Pedro y san Pablo / juntos sino solo san / Pedro, y desto ay los / tantos autores» (fol. 83r).

${ }^{55}$ En el margen del manuscrito de Madrid: «Illipulalaus. / Uno o (?) illpula y / esta de que (?) / llama illupula que (?) / y la pone Plinio (?) / (?) a Illotensi» (fol. 83r).

Nota del transcriptor: Nombre de una antigua ciudad romana posiblemente situada, según los investigadores, en la zona alta de la vega, a las faldas de la Sierra de Alfacar.

${ }^{56}$ En el margen del manuscrito de Madrid: «No era el monte lu- / gar disputado (?)(?) / contigo sino señala- / do para estos santos / porque se tratauan en / el, y castigarlos don- / de cometían el (?) / el llamaran delito» (fol. 83r).

${ }^{57}$ En el margen del manuscrito de Madrid: «No es nuevo enmendar / nombres que an corrun- / pido con inscripciones / antiguas, ni ay porque / tener por fingido nom- / bre el de Aben Athar / entre Árabe como / fue S. Thesiphon. / Ni porque (?) San- / tiago otro, dexo de / (?) estos discípulos / que son muy conocidos / por suyos en los au- / tores» (fol. 83r). 
[Al margen: 6] Sexta ${ }^{58}$. Que los tres santos principales de los / nombrados en las láminas no murieron / en Granada sino en diuersas partes donde / fueron obispos y no se sauian que fuesen márty- / res antes se çelebrauan por confesores, ni / su martyrio pudo ser en las calendas de / los meses que se señalaron pues celebrauan / la Yglesia de España a quince de Mayo. /

[Al margen: 7] Séptima ${ }^{59}$. Estauan compoca [sic] decencia las reli- / quías y libros, sin caxas y sepulchros como / lo requeria ny hussaua la piedad de los cristia- / nos de aquellos tiempos, y como pudieron / poner las láminas, huesos y libros junto / las pudieran poner decentemente. /

[Al margen: 8] Octaua ${ }^{60}$. Parece dificultoso que //22r aya ${ }^{61}$ escrito San Tesiphon en lengua Aráuiga / con caracteres de Salomón que trae muestras / de fingimiento con el mismo nombre. /

Nona, el título del libro fundamentum [Al margen: 9] / ecclesiae, parece el que condenó Gelasio $1^{\circ}$ como / está en su decritos el de Essencia dei no / parece de aquellos tiempos pues la palabra / essentia a [sic] sido usada de los theologos medernos. I

[Al margen: 10] Décima ${ }^{62}$, el latín de las láminas y forma de / letra dellas parece fingido por desmentir antigüedad. /

${ }^{58}$ En el margen del manuscrito de Madrid: «No probará que no mu- / rieron en Granada / porque (?) aya quien / diga que (?) en / su (?) [tachado] / [tachado] refiriendo por sus / nombres los siete dis- / cipulos basta que se / verifique en los más / y san Cecilio su ciudad / era Granada. /

»El llamarse los mártires / confesores sabida cosa es / que se llamaron así porque con- / fesauan públicamente fe / (?). /

»Y ay muchoas que sabemos que fueron mártires en el martirologio / con solo este nombre de confesores. Y la Iglesia / y martirologio los celebra en verdad en que se (?) / a san Torquato fue el último que murió (?) que era com- / pañeros todos siete discípulos de Santiago. Ni es (?) / (?)isimos que muriesen en martirio en distintas partes» (fol. 83r).

${ }^{59}$ En el margen del manuscrito de Madrid: «No es buena razón que por- / que (?) dejar de po- / nerlos como es ta(?) / le tendrán de ponerlos / mejor ni la pa(?)/(?) diría a ello lu- / gar» (fol. 83v).

${ }^{60}$ En el margen del manuscrito de Madrid: «Mayor dificultades que / aya sido (?) de San / Tiago en esta misma lengua / Arábiga y ay escrito va- / ríos libros en ella dictan- / doselos el Apóstol, o / la Virgen como ellos se / dize» (fol. 83v).

${ }^{61} \mathrm{Al}$ margen: «Mayor difficul- / tad es que aia sido / Secretario de San / Tiago nesta / (?) a lengua / Aráuiga y aya / escrito varios / libros en ella / dictándoselos / el Apóstol a / La Uirgen como / en ellos se dice» (fol. 83v).

${ }^{62}$ En el margen del manuscrito de Madrid hay una anotación al margen que apenas se puede leer con claridad (fol. 83v). 
[Al margen: 11] Undécima. Centulio, Lupario con los demás / se dice auer padecido con los tres principales / no son conocidos en la Yglesia y deuen ser [tachado: conocidos] [al margen: canoniçados] / por el Pontífice ${ }^{63}$ aquí en esto toca antes / de ser dados por santos y Reuerenciados por / tales y se añade que sus nombres traen Argumento / de ficción. /

[Al margen: 12] Duodécima ${ }^{64}$. Como estuvieron estas Reli- / quías y libros tanto tiempo sin descubrirse. /

Otros añaden lo siguiente. //22v

[Al margen: 13] Decimo tercia. Si se pusieron allí los libros antes ${ }^{65} /$ del martirio como no se derritieron con el fuego / del siendo de plomo y lo mismo las láminas / y si después como no pusieron las reliquias con / la decencia deuida y husada [sic] en aquel tiem- / po como queda dicho, pues pusieron los libros / y láminas con tanto cuidado y recato y como / tuvieron tanto y tan particular tiempo para / a questo, lo tuvieran para lo otro que era me- / nos i ympotaua más. /

Iten los tres libros que dicen puso allí el Apos- / tol entre las dos piedras, y a estauan allí antes / de ningún martirio pues como no se derritie- / ron con tantos y tan grandes fuegos como en / aquellas cavernas hubo. /

[Al margen: 14] Decimaquarta. Cossa sauida es que los moros que / poseyeron tantos centenares de Años a Gra- / nada $^{66}$ se enterrauan en la parte

${ }^{63}$ En el margen del manuscrito de Madrid: «El pontífice dio comi(?) / no (?) a todos / por los nombres y (?) / que se calificasen su (?) / docamente el memoria / y en las laminas parece / que la iglesia primitiva / los veneró y tuuo por / santos mártires quan- / do (?)(?) de- / creto (?) del pa- / pa» (fol. 84r).

${ }^{64}$ En el margen del manuscrito de Madrid: «Este es lindo (?) / te asi (?) otros / muchos y están» (fol. 84r).

${ }^{65}$ En el margen del manuscrito de Madrid: «Los libros se pusie- / ron lo más antes / del martirio otros / y laminas después / más todos los libros / estauan escritos an- / tes, no se derritie- / ron porque estauan le- / jos del fuego y (?) / se hallaron con bastan- / te destrucción de los hor- / nos. /

$»$ Las reliquias con (?) / decencia se hallaron / puestas pero se cono- / ce claro que se pusie- / ron con poco tiempo / y parte del se lleuó / el escriuir las lámi- / nas que de(?) los que / eran y fue la dili- / gencia que (?) impor- / tancia. /

»Ya se dixo que estauan / distantes del fuego / pero de la (?) / (?) de Dios creo que en / medio dellos vieron / (?)» (fol. 84r).

${ }^{66}$ En el margen del manuscrito de Madrid: «Notable dispa(?) / y parécele que alcan- / zado traza como / hazer posible que / esto sea ficción no / imposible es que no / hallo otra traza / la qual es (?) 
contraria de / aquellos montes que está dentro de los muros / donde la Torre del Azeytuno hasta cassi la //23r Puerta del sol o de Guadix. Por la parte que / miran a mediodía la qual tenía dos nombres / en Aráuigo y los conserua este oy entre los de / esta lengua Al-Rauita que quiere decir her- / mita o soledad poe agunas hermitas de mora- / uito que deuía hauer en aquella parte y / el otro nombre era Arrauda, que significa / sepultura onrrada y rica, y en esta parte / hemos [tachado] [al margen: enterranse] muchos de los combertidos / al Maometanos hasta el año de 1562 aunque / les costaua caro lleuar tan lexos la cruz y cléri- / gos y dieron esto muchos dellos que biuen oy y / era tradición bien sabida entre los viejos / de aquella Ciudad naturales antiguos della / que de la otra parte de los muros destos mismos / montes que es la que mira $<$ al $>$ oriente y dose ha. / llaron las láminas, huesos y libros se costum- / braron a enterrar los judíos que hubo en aue- / lla ciudad de Granada, asta su conversión y es / cossa muy sauida por la escritura sagrada //23v y experiencia que estos se enterraron y entierran / en quebas ${ }^{67}$ y espelunias y hubo gran cantidad / de ellos en aquella Ciudad. Pues que sería que sa- / bien<do $>$ los Mahometanos que hauía allí cuerpos / de los judíos hubiesen por el odio natural que estos / tienen y por desprecio y (?)efa hecho allí su ca- / leras y convertido los como dicen en cal, de- / xando allí sepultada la parte ynutil della y / allegando a sauer algo desto algunos de los / descendientes de Mahometanos juntos con / erejes orientales de la lengua Aráuiga y / setentrionales ubiesen querido por sus in- / tereses burlarse de la yglesia latina y tur- / barla con semejantes nouedades. //24r

Tratado último de la doctrina de los / libros. /

/ caso y del hecho / lo primero no solo no / es cosa sabida pero / nadie creo yo lo di- / ze sino el que judíos / se enterrasen hazia / aquella parte de la / ciudad (?) dado / que así fuera no tan / lejos como esta el (?) / te (?) ni con tan- / tas que (?) en / medio (?) / de fazer.

»Tampoco se sabe que / muros en (?) que / los vi(?) muchos ju- / dios (?) a sus / sepulcros, ni (?) / to los para que ma(?) / (?).

$» Y$ si esto fue en nuestro tiem- / pos después que Granada / (?) se (?) que no / se como (?) allí me- / nos hasta el año de (?)95//84v que se descubrieron / casualmente y se / hallaron todas (?) / plenadas y los plo- / mos envegecidos y / conuertidos en par- / te en tierra que de / cosa que no se pue- / de fingir con arte / la tiempo de (?) / quien mui de po- / ner allí la dotrina / de cristianos y se / rraplenar todo / aquello que es mu- / cho pues con 20 / peones se tardó / dos meses en ha- / brirlo, pero / confesemos lo que / he horrible (no / siéndolo) es buen / argumento pudo / ser luego fue? Pudo / no auer nacido / san Juan, pudo / no auer sido de- / gollado luego ni / nacio ni fue dego- / llado siendo d(?) / later(?)ria.

»Lo que parece verosímil es / que al Juez de Ner(?) por- / que no si se que (?) / ni veneran aquellas / ca(?) los mandar en- / terrar(?) y inter(?) / niendo (?) de los / que eran ya cristianos / en forma a la heredad y / descubrir (?) con /(?) las cenizas y / [texto perdido]» (fols. 84v-85r).

${ }^{67}$ Lease: cuevas. 
Capítulo $1^{\circ}$ de los libros que yo ui y in- / terpreté. /

Puesto e Beatísimo Padre la narración simple / y llana de todo lo ablado, que es lo material / desta información, lo esencial della es la / doctrina de los libros en decir la qual me a- / bre de detener algo más por lo que importa a la / Yglesia, y dexando a parte los pedaços de algu- / nos libros que ui y títulos de ellos que copié / diré solamente los que interpreté ad uerbum, y de / uno [tachado: que] solo que copié con su forma y lengua que son / los que importan que el señor cuya es esta Causa / Permitió que biniessen luego a mi poder por manos / del Arçobispo el qual me los mandaua ynterpre- / tar de el libro Fundamentum ecclesiae. I

Este fue el primero que bino a mis manos, tiene / el título siguiente: Libro de los fundamentos / $/{ }^{24 \mathrm{v}}$ de la ley, y Libro de los Artículos de la ley y de / The$\underline{\text { siphon discípulo de Jacabo Apóstol }} \underline{68} /$

En solas cinco ojas [sic] comprende casi todos los ar- / ticulos de la fee con alto y graue estilo y lengua- / ge, y me persuadí al principio que era el símbolo / o concilio que hicieron los apóstoles antes del mar- / tyrio del glorioso Santiago Apóstol antes de di- / uidirse a la predicación, y no esto y de contrario / parecer aunque le agan añadido herejes algo / para sus intentos como suelen. /

Los errores que noté en él son: /

[Al margen: 1] Primero tratando de la processión de las perso- / nas diuinas diçe que ${ }^{69}$ el padre engendra al hijo / por el spiritu santo o con el spiritu santo. I

[Al margen: 2] Segundo que se descubriría quando ${ }^{70}$ se enterra- / sen en los templos los malos con los santos. /

${ }^{68}$ En el margen del manuscrito de Madrid: «Dio sobre este libro / y el de (?) / parecer (?) / traducido con (?) / dado y dixo que era / todo dictado del / spiritu santo y / que ninguna propo- / sición se podría (?) / (?)(?) tra- / ducir en sentido que / no (?) católico, yo / e uisto el (?) ori- / ginal y (?) coia / que es larga y fundado / (?) se contradize» (fol. 86r).

${ }^{69}$ En el manuscrito de Madrid inserta después del «que»y antes de «el» dos barras oblicuas y sobre ellas una «A» que remite a una anotación al margen que dice: «No ay tal proposición en el libro ni la po- / día mostrar» (fol. 85r).

${ }^{70}$ En el manuscrito de Madrid pone una cruz sobre la «u» y en el margen junto a otra cruz pone: «entierranse en (?) / la (?) Alemania / y Francia, (?) los re- / yes y otros señores / (?) en los (?) / (?) santos (?)» (fol. 85r). 
[Al margen: 3] Iten que se auía de descubrir para ${ }^{71}$ amparo del / clero en los últimos fines en este esta lo que diçen / que ay en estos libros aprobando la puríssima / conçepción de Nuestra Señora porque (si bien me / /25r acuerdo) pone estas Palabras ${ }^{72}$ : Adán fue sin padre / ni madre eua de padre sin madre, Jesús de madre / sin padre, y en <es>ta Generación no alcanço a María el / pecado Primero. I

Tiene otras dificultades como es una comparación ${ }^{73}$ / que pone en la procesión y en las diuinas Perso- / nas y otra de las partes de la Cabeça comparando/ las a la iglesia que ay que notar en ellas como / note quando tenía el original y ahora por hablar / solo de memoria no pudo. /

\section{Raçon de lo apuntado en este libro. /}

Auiendo notado [tachado] santíssimo padre / lo que he dicho, parece que me corre obligación de / dar Raçon porque lo noto; como la daré de los de- / más libros cuyos errores son muy mas claros / y mayores. $\mathrm{No}^{74}$ e topado este error por los / mismos términos que el padre por el spíritu santo / o con el spíritu santo engendre al hijo. Pero / vese claro que es de Noelio ${ }^{75}$, Sabelico o Pris$/^{25 \mathrm{v}}$ ciliano de las que decían que las diuinas Personas / no son yguales como Arrio o de los metagismonitas / que significa los que ponen un basso dentro de otro / a la qual parece que corresponde la deste libro, y es / mucho detemor que sea assi pues duro este error / en España traído de los Godos que la ocuparon / y poshieron más de 300 años y Prisciliano / enseñado de Siros y caldeos en la astrología / Judiciaría y en los errores de Arrio hiço gran / daño en estos Reynos. /

${ }^{71}$ En el manuscrito de Madrid pone sobre el «para» una «B» que remite a una nota en el margen: «No ay tal palabra en / este libro. Ni quando / lo (?) in / conueniente» (fol. 85r).

${ }^{72}$ En el margen del manuscrito de Madrid: «No se acuerda ni / sin esas las pala- / bras, habla sin te- / ner los papeles» (fol. 85v).

${ }^{73}$ En el margen del manuscrito de Madrid: «Y en excelentes los / comparaciones y / de mucha estima / claridad y no / es esta comparación / en las procesiones / de las diuinas perso- / nas sino en el (?) / como se(?) los / (?) personas de / la encarnación y quan- / do se (?) en la / (?) del misterio / de la trinidad tiene / sentido católico (?) / que no se pone (?) / procesión del spiri- / tu santo sino se su- / pone» (fol. 86v).

${ }^{74}$ En el texto del manuscrito de Madrid aparece sobre el «no» la letra «C» que hace referencia a una nota al margen: «Confiesa que no / a hallado este error / en el libro y si no / le ay que importa (?) / (?) que en otras y cu- / io fue» (fol. 86v).

${ }^{75}$ En el texto del manuscrito de Madrid sobre «Noelio» aparece la letra «D» que hace referencia a una anotación al margen: «Contra todos error here- / jes(?) doctrina espre- / sa en muchos fuentes / desde libro y de los que / se hallaron juntamen- / te con él en el sacro- / monte» (fol. 87r). 
Quando a lo que diçe que se descubriría este libro $^{76}$ quedo / se enterrassen en los templos los malos con los / santos, se trata allí de los pecadores y toma los / templos por lo que communmente se toman que / es por las yglesias materiales con sus partes y çi- / menterios donde se juntan los fieles cristianos [al margen: a celebrar los di[vi]nos misterios] / en los quales se acostumbraron a enterrar los / fieles, y ase vee que es señal sin fundamento pu- / es dende que ay templos se començaron a enterrar / los fieles y buenos cristianos con los malos y / si aputamos [sic] más este dicho tomándolo por solos $/ /^{26 r}$ los templos y no por los cimenterios aludiendo / a la antigua costumbre que ninguno se enterrase / dentro de ls iglesias sino era tenido y venerado como / santo, y esto fue assi por mucho tiempo, aun be- / mos que asi es también fuera de propósito el dicho / pues a ya más de 500 años que se entierran todos / buenos y malos dentro de las Yglesias, y mucho / más onrrada y grauemente los tenidos por no / tan buenos y estos ${ }^{77}$ se toman los más altos y gra- / ues lugares, y aun se eligen sepulturas en los / huecos de las paredes, y a par del Santíssimo Sacra- / mento, y según esto, se auía de hauer descubierto / este libro 300 Años atrás y si se dixesse que habla del enterrarse los infieles en los lugares sagra- / dos juntamente con los fieles tomando a los infieles / por los descendientes de Mahoma, o de otros no (?)i / en conuertidos o que no creen como deuen. Ha- / llaremos que aun así no lleua fundamento poner / tal señoal, pues la iglesia que no juzga lo o- / culto d elos coraçones los reciue como hijos y / no juzga sin causa ni fundamento ninguno $/ / 26 \mathrm{v}$ Por indigno de sepultura Sagrada, antes orde- / na que se les de a todos los que fueriin conde- / nados por ella como indignos desta sepultura / y aun asi auía de hauer más de 100 años que / se auía de hauer descubierto pues a mas que esto / passa en nuestra España. Añádase a $\mathrm{lo}^{78}$ / dicho que no parece señal de Dios ni de santo / suyo la que no tiene nada de su spiritu el qual ha- / ce todas las cosas compesso [sic] y medida y

${ }^{76}$ En el margen del manuscrito de Madrid: « Los reyes de Inga- / laterra se entierran / o y erajes donde es- / tan enterrados sus / antecesores santos y otros muchos / e razón en templo / y la iglesia nunca / a permitido ere- / jes ni des(?) / gados ni peccado- / res manifiestos / que murieran in pe- / nitentes manifies- / tamente como los / que se ahorcan en ti- / rarse, oy ya (?) / opinión que ensan- / cha y facilita / no se uso enterrar- / se los erejes en los //87r templos con los ca- / tolicos y menos con / los santos jamas has- / ta nuestros tiempos de / antes aun los catoli- / cos se (?) y / se contentaran en en- / terrarse en los cemen- / terios (?) aun- / que fueron grandes prín- / cipes hasta tiempo / de Constantino» (fols. 87r-87v).

${ }^{77}$ En el margen del manuscrito de Madrid: «Estas cosas es que se / usa de poco tiempo / a esta parte y la / (?)(?) es (?) / del tiempo que aya de / ser el mismo dia / que se comienza has- / ta para verificar / que sea la tiempo que / se haze y usa» (fol. 87v).

${ }^{78}$ En el margen del manuscrito de Madrid: «Señales de harto / dolor ver que en / tierras erejes con / los santos y el pa- / sar la (?) señal / de perdición es / reprehenderla y / todo es útil y co- / mo de quien es / la dotrina y pro- / fecia que haze ver- / dadero esto y lo / confirma» (fol. 88r). 
tales de suyo que muestran bien el autor cuyas son / y all reues las del enemigo del genero huma- / no son sin fundamento y orden, dudossas / que se pueden atribuir, a uarias cosas y tales / de suyo que dexando los ánimos con mayores perplexidades ${ }^{79} \mathrm{y}$ dudas que pueden atribuirse / a diuersas cosas: uso propio de herejes para $^{80}$ / entretener los varios discursos de los ignoran- / tes y para esto diçensentencias sueltas como las / hiço el peruerso Mahoma en todos sus escritos / y lo husan los Hereges antiguos y modernos / y tal parece ser esta señal. /

$\mathrm{El}^{81}$ decir que este libro es para amparo del clero $/ /^{27 \mathrm{r}}$ en los últimos fines que de tener buen sentido / diciendo ser aquel amparo dirección y guía por / sauer mejor gouernar con mayor consuelo vi- / endo que siendo antiguo confuta las heregías mo- / dernas que sería de gran fruto. Pero de lo pasa- / do parece claro que se infiere que aquel amparo / denota más y assi se pude temer que encubi- / ertamente quiere decir que entonces el clero / entenderá algunas verdades no sauidas y ne- / cessarias para su dirección porque no caue en Ju- / ycio discreto entender que aquel libro puede por / si amparar al clero, ni por su doctrina, pues a de / estar expuesta a lo que están los libros sagrados / y canónicos de la iglesia, que es aquello / que no los admiten y siguen otras se[c] tas, $\operatorname{los}^{82}$ / tengan por falsos y aunque no están declara- / das todas las verdades y toca a esa santa silla / el declararlas que son de fee según los tiempos / y necesidad dellos, es también de fee que ja- / más a faltado, ni falta ni faltará toda la doc- / trina necessaria para saluarse los hijos //27v della ni la dirección del clero para esto. /

En lo que lo que [sic], que dice de la Purísima Con- / cepción de Nuestra Señora aunque el lugar es bueno / para lo que deseamos ver de fee, se puede expli- / car $^{83}$ que quando María concibió al Hijo de Dios / no alcançó a la

${ }^{79}$ En el margen del manuscrito de Madrid: «Las prophecías no / son todas claras / lea los prophetas / estos tienen seme- / jantes en el euan- / gelio y libros sagrados / ni [no se lee claro]» (fol. 88r).

${ }^{80}$ En el margen del manuscrito de Madrid: «Calla no blasfe- / mes» (fol. 88v).

${ }^{81}$ En el margen del manuscrito de Madrid: «No diçe que es para / amparo del clero / y todo el discurso / (?) y sin eso es disparate» (fol. 88v).

${ }^{82}$ En el margen del manuscrito de Madrid: «Según esto (?) / juzgará por imper- / tinentes los libros / sagrados recibidos, / el impertinente / es él que no (?) / la de los escrituras / como deue que ellas / (?) son / sobre manera y / si se recibieren es- / tos libros por (?) / correrán la misma / razón pues ya / en tal caso serían / recibidos por escri- / turas sagradas» (fol. 89r).

${ }^{83}$ En el margen del manuscrito de Madrid: «Dezir que estos libros / pretenden negar la / diuinidad de Cristo / es mentir clara- / mente porque el / mismo (?)(?) el / (?) fundamento / eclessiae y es el (?) / (?) no tenemos de / cinco hojas ay muchos lugares ex / (?) de la / diuinidad de Cristo /entre 
sacratíssima humanidad el pe- / cado original y si el libro fue corrompido por he- / reges y más Nestorianos más parece que tira / a este negándole la diuinidad que es lo que prente- / den estos libros secretamente y dándole lo que / nosotros damos a su sacratíssima madre. /

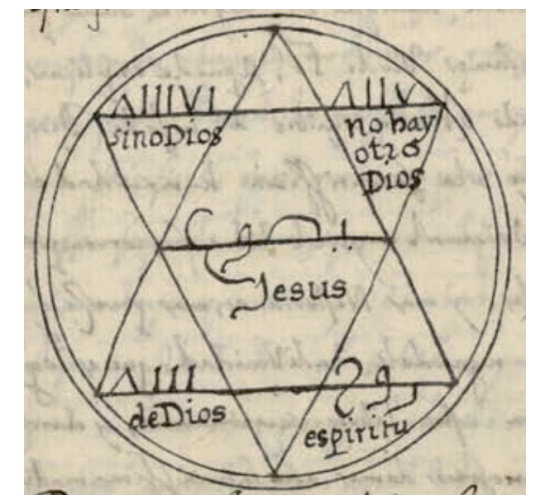

Capítulo 2. Del Anillo o sello de Salomón. /

Entre los libros que e [sic] contado que se hallaron es- / tando yo con el Arçobispo, pongo en el número 8 / este. Segunda parte de prouidencia, en este / ay otros tres tratados de Ángeles, del Anillo o / sello de Salomón y de veata Patria. /

Pretendió el Prelado entender lo que contiene / este libro. Traduxe solo lo del Anillo y lo copié / en la primera oja de cada libro esta un $/ / 28 \mathrm{r}$ sello de un triángulo en otro en esta forma ${ }^{84}$. I

De la significación de las letras. /

La significación de las letras Aráuigas la que pongo / [tachado] deuaxo en castellano y aunque pare- / cen cathólica es el símbolo que tuvieron $\operatorname{los}^{85} \mathrm{Nes-}$ / torianos y Arrianos para negar la diuinidad / de Jesuchristo, y de ellos y de

otros Con- / nenit autem / sumptio corpo- / ris Dei nos ni / veriles usicut / sump serant illud / Apostoli ett / que mas claro la diui- / nidad de Cristo y la / verdad de su cuerpo / en el santísimo Sacramen- / to del altar» (fol 89r).

${ }^{84}$ En el margen del manuscrito de Madrid: «En algunos de / los libros ay este / sigilo aunque aquí / no está bien hecho» El sello reproducido es el del manuscrito (fol. 89v).

${ }^{85}$ En el margen del manuscrito de Madrid: «De (?) probar / y contra estos era (?) / oy expresa doctrina / en los libros del sacro- / monte» (fol. 90r). 
los demás Hereges / antecesores lo tomaron los sequaçes de Maho- / $\mathrm{ma}^{86}$ y la an husado siempre y husan oy $/ / 28 v$ della en esta forma No ay un dios sino Dios / y Mahoma su embiado, con la que profesan su / falsa vida y quando hablan de Jesus la entienden / assi. No ay otro dios sino dios, no diuidido en / perso-

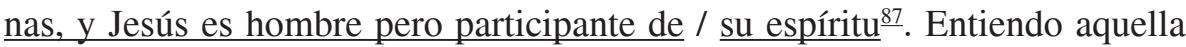
palabra, espíritu de / dios instrumentalmente. Esto se puede deuer en un / libro que preçian los Mahometanos cuyo título / es: Alvum dafi Xarchi Alburdas. /

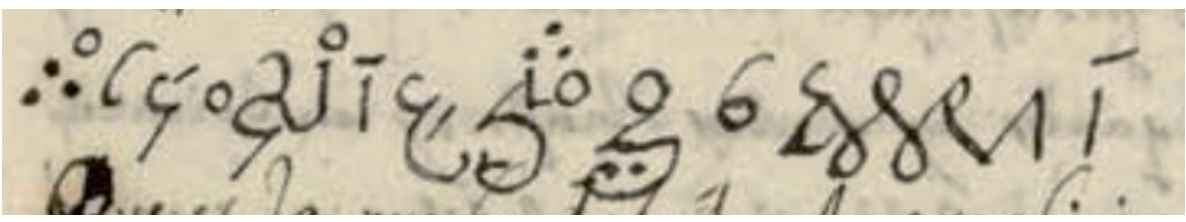

que es la profundidad en la exposición de la Bor- / da. Esta Borda una Cançion o elegía que tiene / de Mahoma exponela un antiguotenido por / gran doctor entre los Árabes y el verso dice:

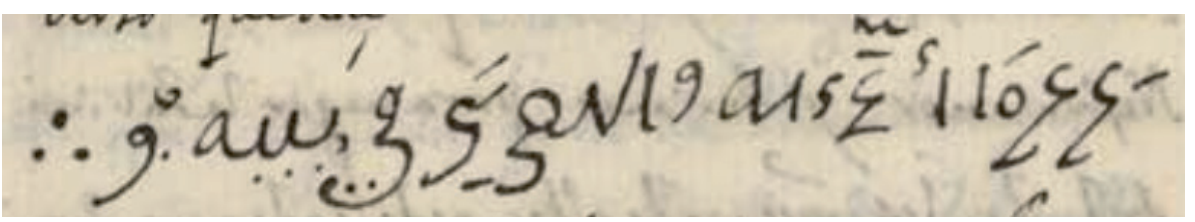

Daaa ma adaa athu al naçara finabithin. /

Dexate de lo que reconocen los cristianos de su pro- / feta trata largamente lo que nuestro redem- //29r tor dicen el Alcoran y sus expositores quitan- / dole la diuinidad y diciendo que lo que se dice que / es spiritu de Dios, Alma o palabra es instrumen- / talmente como el que tiene el cuchillo en la mano con / el qual corta la pluma. /

El intento que claramente parece que tubo el que / puso $^{88}$ este sello en todos los libros y con este mismo / título fue para autoriçar el símbolo o pro-

${ }^{86}$ En el margen del manuscrito de Madrid: «No ay otro dios / sino dios no / son malas pala- / bras. Mahoma / su embi[a]do no / lo dizen los libros / del monte sacro / y la doctrina de los / libros es expresa / contra mahometa- / nos» (fol. 90r).

${ }^{87}$ En el margen del manuscrito de Madrid: «Esto es una maldad / suya (?)que a / estos dos (?) está / expreso que es Padre / hijo y spíritu san- / to, tres personas / una e (?) / solo Dios» (fol. 90).

${ }^{88}$ En el margen del manuscrito de Madrid: «Gran maldad vien- / do la doctrina contra- / ria expresa inter- / pretar la instancia / en cosa que es me- / mester mucho vio- / lentalla aunque no / se (?) / do sino para que / diga lo que el quiere» (fol. 90v). 
tes- / tación dicha de los Nestorianos de los queles ay mu- / chos <asta oi> en Oriente, y ahora autoriçalle diçe en el libro / que in titulo del selo de Salomón, que la Virgen / Nuestra Señora auía contado su historia y como co- / sa muy cierta mandado se escriuiesse. /

En ninguna parte de ningún libro llama a Jesús / hijo de Dios sino spíritu de $\operatorname{Dios}^{89} . /$

Hauiendo entendido esto por carta del Arçobis- / po la buena memoria de Benito Arias Monta- / no le respondió que tenía y aun tenía por pro- / bable que los libros hallados eran cossa de he- / reges pues husauan este término y frasi en to- / dos ellos y aunque se le hiçieron argumentos $/ /^{29 v}$ de que la sagrada escritura llama al hijo de Dios / spíritu de dios y ello así, jamás le pudieron sacar / de su parecer por no decir si quiera alguna vez / hijo. Y assi nunca le pudo ynducir el Arçobis- / po a querer corresponder con lo que tan ahincada- / mente le suplicaua de uenir a Granada por no / pareçer que authoriçaua aquello con su presen- / cia. Vi yo cartas suyas sobre todo y en todas de- / cía llanamente que tenía que eran engaños de / Hereges y si esto decía co sola una uislumbre / sin sauer lo particular de la doctrina de los libros que dixera si la supiera. /

Aunque $^{90}$ todos los libros no tuvieran otra dificul[tad] / mayor sino la de estas Palabras y símbolo pues- / to en este sello o signo que llaman de salomón

${ }^{89}$ En el margen del manuscrito de Madrid: «Esto es falso y / mentira por que él / vio el libro y yo / lo e visto y en / más de una parte / está (?)(?) / tra dicho en los / libros que Jesús es / hijo de dios encar- / nado en la María / Virgen. /

»En el libro Fundamen- / tum ecclesia. /

»Dios junto su misericordia / y su justicia para medias / por el hombre con forma / a la grandeza del pecado. / Fue grande y no auia con- / que satisfacer por el / y conmino a Dios por su / misericordia y vest(?) / exinanición a su hijo / por la unión de la (?) / umanidad y diuinidad. /

»Arias Montauo se / escudo por enfer- / medad de venir / a Granada y acusa / que los libros fueron / falsos era (?) / interpretando pa- / ra aueriguarlo / pero el no sabía / árabe tenía (?) /(?) crédito adqui- / rido en (?) / que (?) (aunque / lo sabía) au(?) / (?) mucho / en ve(?) lexa / men y atención / del arzobispo don / Pedro de Casto que era / tan [el texto queda confuso aquí]» (fol. 91r).

${ }^{90}$ En el margen del manuscrito de Madrid: «Ser tan santos estas / palabras y símbolo que / expresamente está / declarando en los / mismos libros que / aquí no lo a decir (?) / sos encarnado por / obra de spíritu san- / to id est per espi- / ratio (?) dei, (?) / [no se puede leer el texto] / factum est,

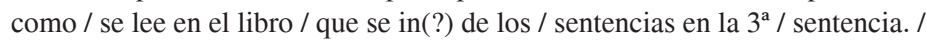

»Solo de los dos triangu- / los uno dice todo otro / es (?) de (?) / (?)nidad con la huma- / nidad. /

»(?) el Arzobispo licen- / cia y breue de su santi- / dad para la calificación / de las reliquias. /

»Esta relación que haze / sumaria no está como / conuiene ajustada y / no ay historia sagra- / da que no se pu(?) in / (?)(?) blasfemo de- / zir de (?) que pa- / reciera de menos / grauedad an visto / este libro doctrinos / hombres y les a parecido muy de (?) / manera que al padre / Casas y entre otros lo / confirma una (?) / (?) con mi poder / el padre Diego Granado S.I.» (fol. 91v). 
/ fuera cossa muy justa y puesta en Raçon el a- / uer reparo el preplado y no calificar hue- / sos y çeniças antes de consultar a (?) santa Silla / Apostólica quanto más teniendo los que he dicho y diré. I

La historia deste libro o sello de salomón a A- / nillo suyo es que la Virgen contó a los Apóstoles / /30r que Salomón tubo un Anillo o sello en el qual / tenía encerrado todo sus sauer y sciencia y con él / sujetaua [texto tachado] los espíritus y los hombres, / lasbestias, al Mar, y los uientos, y que quiriendo / entrar a bañarse le dio en guarda a una de sus mu- / geres, y el demonio por embidia se apareció a esta / en figura de Salomón y le pidió el Anillo y lo ar[r]o- / jó en el mar y saliendo salomón del baño y pidi- / endo su anillo entendió el fraude y engaño y se / alló sin su sciencia y lamentándose y afligi- / éndosse mucho le fue auisado de parte de Dios que / fuesse a la riuera del mar donde ayudó a unos / pescadores a tirar la pesca, los quales por su Pre- / mio le dieron un pez dentro del qual halló su a- / nillo y con el recobró su sabiduría ${ }^{11}$ perdida / y Reyno y concultó los ideolos y uino largo / tiempo. Esta es la cifra deste libro. /

Raçon deste sello. /

Lo que barios autores dicen a cerca del sciencia y / sauer de Salomón en conjurar los spiritus ${ }^{92}$ re- $/ /^{30 v}$ coge en breue el Ilustrísimo Cardenal César Boronio en / su Annales, en el año de 16 de Cristo Nuestro Señor / y doce de san Pedro nuestro señor. tratando / de san Pablo y to- / cando aquello de los actos de los Apóstoles cap. 19 / tentauerumnt auten quídam estt y aquello e $\underline{\text { e- } / ~}$ rant autem cuiusdam iudezi nomine sceva / principis sacerdotum septem filii ett ${ }^{\mathrm{a}}$ _dice así: / exorcisae erant non ignobiles vivi iudçorum / sed filij Principis sacerdotum [al margen: arcanum] fuese amaioribus / traditum ministerium deamones expellendi, ne / communi ómnibus. Y añade luego: / que primus ómnium haec do cuit hebreos salo ${ }^{93}$ - / monem fuisse Josephus affirmat sic $\underline{\text { dicens Pres- }} /$ titit autem deus atiam salomoni ut contra de- / mones artem ad utilitatem hominum et eorum / curas e diceret incantationes etiam in stitu- / it quibus adstrictidaemones, ne denuo vede- / ani effugantut et haec cura hastemus apsu nos / multum praevalere dignitur vidi etiam / quemdam eleazarum ett. Refiere como este / saco un demonio delante de Vespassiano y no //31r parecer que nada de esta reprueba el Cardenal, an- / tes añade que el mismo

${ }^{91}$ Hay una palabra en la interlínea pero no se puede leer bien.

${ }^{92}$ En el margen del manuscrito de Madrid: «Pretendo aquí el / hazer osten- / tación de esa di- / cio a en gran parte / con el tratado de / otros y todo ello / de poca sustancia / para el efecto» (fol. 92r).

${ }^{93}$ En el margen: «Joseph. Lit 8. / Antiquis. Cap. 2». 
Josepho refiere de radice / quadam admirabilem virtutem habente pellendi / daemones. Lo qual parece hauer tomado el dicho / Cardenal Baronio del Cardenal Hugo sobre a- / quellas palabras del libro $3^{\circ}$ de los Reyes Cap. 4 / et diserbit de iumentis donde refiriendo co- / mo estas obras de Salomón fueron quemadas / con la Blibia [sic] por Nabuzardan, añade: nee / fuerunt referta cum allijis libris quos habemus. Di- / ce luego: Excogitauit etiam Salomon ad iura- / tiones quas dam quibus aegritudines solent mi- / tigari: allias quoque, quibus daemones obstricti / non redibant excogitaui ett ${ }^{2}$. [texto tachado] [al margen: Cara(?)] qui / in seribibantur gemmis quae antae pos $<$ te $>$ naribae / arreptituij cum radice quadam Salomoni mo- / nitrata statim illum a daemonibus liberabant. / Hac [texto tachado] [al margen: scientia] plurimum valuit

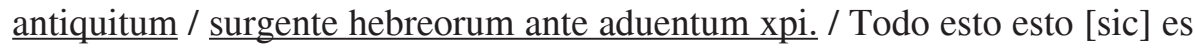
de Hugo y luego poen lo que / e referido de [texto tachado] [al margen: baçar] exorcista sin repro- $/ /^{\beta 1 v}$ uar nada de esto este graue autor. /

Cayetano sobre el mismo Cap. 4 lib. 3 Reg. Dice / estas palabras: et nihil in spetie decit seriptum / aut dictum de Astris nihilde uocatis exorcismis / aut daemonibus. /

El Abulense pone más latamente [sic] lo dicho en este ${ }^{94} /$ modo: fuit etiam Salomon peritus circa daemo- / num inbocationes et dictiones de corporibus / fuit atiam peritus circa amnem negromantia / et superstitionsam artem quamq ibi proprie non / sit peritia. Y sobre aquellas palabras de la / Sabiduría ${ }^{95}$ : $\underline{\text { suit }}$

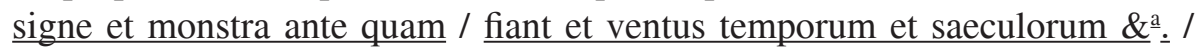
Dice que supo la Astrología indiciaria pra[c]- / tica de los hombres y para esto alega el cap. 7 / de la Sabiduría: scibis disposiciones estellarum / et cogitationes hominum et que(?) que / sunt absconta, et inprouisa didici, y dice / este autor que aunque no se puden saber / los pensamientos de los hombre se puede $/ /{ }^{32 \mathrm{r}}$ conocer lo que el hombre a soñado, nisi forte som- $/$ nium a Deo sir, spiritualeiter inmissum quia / non habent radicem ali quam inconditione na- / tura, y apruebalo con Aristóteles y al fin casi de / la questión y dice assí: Habuit etian sapien- / tiam circa demones expolendo de corporibus un- / de ipse instituit exorcismos quos indei de dice- / runt ad ad [sic] excludendum daemones de corpo- / ribus et mansrnunt isti exorcista semper / inter judeos usquequo cesauit status judai- / cus per Romanos unde tempore xpi. erant / isti exorciste, et Christus locuitus est de eis ibi si / ego in Beelzebu ett ${ }^{\mathrm{a}}$ filij vestri in quo eiiciunt, / y refiere lo de Eliaçaro delante de Vespasiano. /

\footnotetext{
${ }^{94}$ Al margen: Abul lib. 3 Reg / cap. 3 q $9^{\mathrm{a}}$.

${ }^{95}$ En el margen: Sap ${ }^{\mathrm{e}} .8$.
} 
Todo lo dicho parece que aprueba que Salomón / no solo tubo sciencia contra los demonios sino / que la dexó enseñada y que se puso hasta Nuestro / Redentor y que según esto será berisimil esta / historia del sello, o absolutamente verdadero / y más siendo referido por la Virgen como en e- / lla se dice. //22v

Tengo para mi que sapientissimo Salomón / no enseñó cossa que no fuesse natural y particular / estudio suyo, para llegar a facer quanto sauían / los echiceros y encantadores de su tiempo, como ${ }^{96} /$ los de faraón en el de Moysés, porque no me qua- / dra decir que aquel señor que prohibió com pe- / na de muerte a los israelitas los Pythones y / Pythonisas le diese a Salomón tal Arte, y me per- / suadiría a creer que eran exorcismos sanctos / y no conjuros supersticiosos ni arte humana. / Porque ninguna vale cotra los spiritus que / son superiores, y assí a la misma naturaleça / humana como a todas las artes, ni puede hom- / bre ninguno forçarlos y apremiados ni a entrar / en lugar o cuerpo ni a salir del ni a no volver si / no es con virtud sobre natural y diuina: así / lo determinó la universidad de París el año / (?) 1398, como lo refiere el comentador Peña / en diccionario ${ }^{97}$ y si quisiesse algún por fiar en que / Salomón enseñó arte para esto, fácilmente $/ / 33 \mathrm{r}$ me persuadire a decir que sería illicita y que con- / tenía pacto tanto o expresso con los demonios / y para engañar ellos con esto a los hombres como / hacen asta oy se muestran ser constreñidos, y sa- / lir y no voluer y decirse esto de aquel sauio Rey / no es mucho pues pecó grauemente en otras co- / sas y cometió el mayor pecado de todos que / es la idolatría y el culto de los demonios enga- / ñado de ellos y por esto por cuentura permitió / Dios que sigue más en tantas obras como no so- / lamente inútiles a la República sino aún / perniciossas y dañosas, y por ser tal la que / llaman Clauicula Salomonis o Fabula salo- / monis, está prohibida por la santa Yglesia cató- / lica Romana, véase lo que sobre esto dice Fr. / Nicolás Cymerico en su Directorio $\mathrm{q}^{\mathrm{en}} 43^{98}$. I

Aquellas palabras del Redemptor filij ves- / tri in quo ljiciunt? Me persuado que no hallo / allí nuestro Redemtor de los exorcistas como dice / el Abulense sino de los Apósotoles que / $/{ }^{\beta 3 v}$ por esso añadió ideó ipsi judiçes vestri erunt / como lo dice Eutimio ${ }^{99}$. Si alegan que la vir- / tud del sello, o anilo no es por arte mágica / ni astronomía sino por particular virtud / incluyda en la

\footnotetext{
${ }^{96}$ En el margen: «Deute. 18 / 1 Rey 28 / 4 Rey 23 / 1 Paralip. 10».

${ }^{97} \mathrm{Al}$ margen: «Dictionarium / inquisitorum $2 \mathrm{p}^{\text {te }}$ coment bb».

${ }^{98}$ Al margen: «Directorium / inq. Sito 4 / lym ici 4 / (?) 43 art. 2».

${ }^{99} \mathrm{Al}$ margen: «In cap. 12 (?) / ca. 21».
} 
figura del sello como deci- / mos tenella la cruz. Se que la figura trian- / gular según Piero Valeriano es indicio de / diuinidad. Addunt (dice) magi simplex trian- /gulum aequilaterum diuinitatis indicium / ese, sivererum caelestium effigiem, y a- / ñadamos a esto que el otro triangulo cruzado / denote la unión hipostática y señal de la / cruz y que por esto tiene particulares virtudes ${ }^{100}$. I Quien no vee que aunque son galones discur- / sos no son fundados ni tienen autoridad aunque / si añada que en ellos se yncluya y encierra / el santo nombre de Dios y en el quanto / encierra la sciencia cabalística. /

Usan oy deste sello en la misma forma y con / el ${ }^{101}$ mismo nombre los Mahometanos en sus / conjuros y quasi no ay libro de Agueros $/ /^{34 \mathrm{r}}$ y echicerías donde no se pongan y aun en tal / los cristianos le e uisto y si en algún tiempo fue / bueno siendo ya tan profanamente usado / y prohibido por la inquisición aparece que / se deue husar sin particulares aditamentos / que le santifiquen como el Lavaro de / Constantino con la A y $\omega$. .

\section{Del libro Historia de la Verdad / del euangelio Glorioso Cap. 3. /}

El título deste libro es puesto llamasse / Hystoria, porque refiere lo que es el libro / illegible cuyo título es Verdad o certidum- / bre del euangelio Gloriosso. /

Su autor dice el mismo libro que fue san- / tiago Apóstol el Zeuedeo y que el le dicto / a san Thesiphon el árabe su discípulo y que / se escriuió en la mismas quebas ${ }^{102}$ donde $^{103}$ / se halló, y que estuvo en ellas el Apóstol / con sus discípulos quarenta días. Su histo- $/ /^{34 v}$ ria es que después de la Ascensión juntó / la Uirgen los apóstoles y les mostró dos libros / el uno que le auía traído del cielo el Ángel san / Gabriel el qual tenía notables resplandores / celestiales, y marauillossa lindeça y hermosu-/ra que lengua no lo sabría decir, y el otro era / de Plomo, traslado de este celestial sellado / por mano de la uirgen

${ }^{100}$ En el margen del manuscrito de Madrid: «Bastante es que aya / todos fundamentos / para hallar (?) / que haga veri(?) / esta historia dest / libro, no (?) / za cabalistica sino / en señal dada de Dios / con(?)te la (?)» (fol. 95v).

${ }^{101}$ En el margen del manuscrito de Madrid: «Esta tradición en- / tre árabes aunque / sean mahometa- / nos no siendo de / su secta antes ayu- / a a(?) que (?) /(?) principio» (fol. 95v).

${ }^{102}$ Lease: cuevas.

${ }^{103}$ En el margen del manuscrito de Madrid: «No dize este libro / que escriuiese en / las cuevas si / de los 40 días / confunde lo con / otro como que (?) / hablaua de me- / moria y sin papeles, y así / es incierto lo que / refiere a delan- / te que contiene el / libro y no es la / forma que en el se / dize» (fol. 96r). 
con el sello de Salomón / de quien ella descendía que así lo diçe el Li- / bro, admirados de (?) los Apostóles pone / varias preguntas que sobre el hiço san Pedro / a la uirgen y lo que ella respondió y porque / está todo por preguntas y respuestas sacare / aquellas conclusiones que importan para uer / su verdad y autoridad. Dejo pues la Virgen / a san Pedro y a los demás Apóstoles que: /

1. Los secretos que el libro contenía no eran / para los apóstoles porque los guardaua Dios / para el fin del mundo para la perfecta / guarda del euangelio. /

2. El traslado de aquel libro se hauía de $/{ }^{35 r}$ guardar en España hasta que Dios lo reuelase / el del ensalçamiento y otro con él. /

3. Del original propio se haría lo que se hiço de las tablas de Moysés / al fin diçe lo que se hiço del en el libro del en- / salçamiento que le uio en el alto trono de Dios. /

4. Llegado el tiempo de descubrirse clamarían / a Dios los Ángeles y Patriarcas y Dios / los oyría y san Gabriel daría un grito y así / se abriría el lugar donde estarían escondidos estos libros. /

5. Descubiertos obraría Dios tantos y tales mi- / lagros del cielo y de los tierra que conbençe- / rían a los muy incrédulos. /

6. Quando se descubriesen los libros cudiçiarian [sic] / los abitadores de quella tierra saber / lo que contenían. /

7. Que se juntarían interpretes para interpretar / lo que estaría en Aráuigo. /

8. En aquel tiempo la lengua Aráuiga se- / ría la común y husada de aquellas tierras. /

9. Quando se descubriesen estos libros moue- //35v ría Dios en Otiente el Ánimo de un / Rey Áraue el qual con sus exercitos de Á- / rabes ${ }^{104}$ uiniese a defender y amparar la / verdad del euangelio Glorioso. /

10. Este Rey áraue con su exercito de Árabes / vendría sujetando lo más de la tierra / hasta estos Reynos. /

\footnotetext{
${ }^{104}$ En el margen del manuscrito de Madrid: «Antes dize no / Árabe y ni duce \& de exercitos de / Árabes» (fol 97r).
} 
11. Los Áraues son de las mujeres naciones / del mundo y su lengua de las mejores. /

12. Que los judíos que crucificaron a Jesús / ellos y sus descendientes asta el juyçio no / se saluarían. /

13. Que Dios a escogido a los Áraues y a este / Rey Áraue para amparar la verdad del / y para esto les da saber y potencia. /

14. Este Rey Áraue auiendo sujetado la tierra / juntaría la voluntad de los reyes para / que juntasen un conçilio universal / en una hisla y en una ciudad de ella. //36r

15. Que este concilio será para tratar de la ver- / dad de la doctrina de el elubro ensalçamiento / que está en el ilegible. /

16. Sobre esta doctrina abrá grandes disputas / entre los doctos de la sciencia única. /

17. Que se fatigarían compenitencias [sic] y humilla- / ciones por entender el illegible. /

18. Embiará Dios un hombre humilde y va- / xo que con luz del spiritu santo le leerá / y interpretará y le creerán todos. /

19. Interpretado verán todos claro quan se- / guido mal el euangelio y su interpretación / y la del Testamento Viejo ${ }^{105}$. /

20. Creerán a la doctrina de 1 que está con el que / es el ensalçamiento. /

21. Serán dichosos y venditos los que se halla- / ren a este concilio y le obedecieren y mal- / ditos y desdichados los que no que sieren ir / a el ni creerle. /

22. Declarado el illegible y admitido la //36v doctrina del otro que está con él por este se con- / uertirán muchos a la uerdad. /

23. Seguirán todos estas uerdades y será la ley una por un po- / co de tiempo y después tornarán a peruertirse. /

${ }^{105}$ En el margen del manuscrito de Madrid: «Es falso / dize lo contrario» (fol. 98r). 
24. Tras esto uendría el antichristo con mayo- / res milagros que los dichos. Todo lo dicho / refirió la Virgen a san Pedro. Prosi- / gue el libro diciendo. /

25. Salió la Virgen con los Apóstoles al monte / Oliueto y orando allí vino una luz y to- / mó el libro original y desapareció. /

26. Tornada la Virgen a su estancia mandó / a Santiago que juntase sus discípulos / y juntos le dio los dos libros y mandó se fue- / sen a embarcar para España. /

27. Mandole entrar en ella por la parte ori- / ental y poner el libro donde por él resu- / citasse un muerto. /

28. Embarcosse en la Naue que le dixo la Vir- $/ /^{37 r}$ gen cuyo piloto era el Ángel Gabriel. /

29. Mandole que predicasse por España y que no / saliesse de ella hasta que le creyesse uno. /

30. Dixole que si fatigaría en ella simprouecho / que su conuersión quedaua para sus discípulos. /

31. Que muchos de ellos morirían mártires don- / de se pusiesen los libros. /

32. Que les mandasse poner ellos allí los suyos / para guía y direction en el fin del mundo. /

33. Que onrrassen y benerassen aquel monte / porque después de los de Jerusalén era ma- / yor y más sagrado. /

También asta aquí halló la Virgen con San- / tiago y prosigue el libro. /

34. Dice Santiago que cumplió quanto le dixo la Vir- / gen y alló la naue y piloto $\&^{\mathrm{a}}$. I

35. Entró en España y llegó a las quebas dichas / sobre el Río Darro que an si se llama aunque / con término Arábigo. /

36. Puesto el libro en tierra tembló ella // ${ }^{37 \mathrm{v}}$ y se leuantó un muerto y dixo el Apóstol que / para que le despertaua de su sueño del tiempo / de Moysés. / 
37. Preguntole quien era, dixo que se llamaua / ALHAC que significa la Verdad. I

38. Preguntó también el Resucitado al Apóstol / quien era y dixole Jacob Apóstol de Jesús, spíritu de Dios. /

39. Yo soy dichoso con él dixo el resucitado man- / dame boluer a mi lugar. /

40. Mandoselo y boluiosse la tierra como estaua. /

41. Repossose el Apóstol 40 días en aquel mon- / te y escriuió esta historia por mano del Áraue / y pusolos libros allí auisó a los discípulos de sus li- / bros y lo que la Virgen le auía dicho de la muerte / de alguno de ellos allí y de la dignidad del monte. /

42. Selló esta historia con sus sellos de Salomón / y en cada uno <una $>$ de estas Palabras: todo es ver- / dad y partiesse a lo que le auía sido mandado. /

Raçon de lo apuntado en este libro. ///88r

Primero ${ }^{106}$ parece claro que el decir que lo con- / tenido en aquel libro illegible no era para los / Apóstoles sino para la perfecta guarda del / euangelio en el fin del mundo es decir que la / Ley euangélica no está perfectamente promul- / gada por los Apóstoles \& ${ }^{\mathrm{a}}$. Porque no se de tan- / t afee a la iglesia esperando la promulgación / perfecta. Fue er[r]or del Abad Joachin y de / Pedro Joan como lo diçe Castro Libro $3^{\circ}$ Aduer- / sus Hereses verbo Apostoli. /

Puntos 3 y $25 . /$

Diciendo como dice en el libro del ensalçamiento ${ }^{107}$ / que uio este libro original junto al alto throno / o silla de Dios, parece que quiere inferir que / las tablas de Moysés están allá que son claras ignoranción. /

Las tablas de Moysés sauemos por fee que fueron / puestas en el arca del Testamento y por ello / entendemos que Jeremías in uenit locum / [tachado:

${ }^{106}$ En el margen del manuscrito de Madrid: «Muy al contrario / desto es lo que dizen / los libros, y en / quanto a (?) / (?) (?) / a los apóstoles en la / que (?) era necesario / adsalutum consta / del mismo euan- / gelio» (fol. 99v).

${ }^{107}$ En el margen del manuscrito de Madrid hay una anotación que no se puede leer bien (fol. 100r). 
ex] spelunce, et tabernaculum et Arcam et al- / tare in cursi in tulit illue et ostium obstruxit. //38v Lo demás de quando se descubrirá esta Arca o si / se a descubierto ya no me parece que es deste lugar, y / graues doctores lo disputan y latamente. /

\section{Puntos 4 y $5 . /$}

Assí como el decir que clamarían a Dios los Án- / geles y Patriarcas y Gabriel daría un / grito se uee la autoridad que tiene tales parece ${ }^{108}$ / que abran sido los milagros que diçen hauer / sido en aquel monte antes de poner allí la Cruz / del Redemptor y después de ella puesta y / santificados y purificados aquellos montes / y cuevas con tantas cruces coo an puesto en / ellas; al crucificado atribuyo yo los milagros / que diçen hauer aprobado el ordinario con ri- / guroso examen, si los a hauido ciertos que / esto de milagros tiene gran latitud, y ay / mucho que decir y pensar en su verdad. / una cossa es claramente falsa en el quinto / punto que descubiertos los libros obraría / Dios tantos y tales milagros del cielo y de / / ${ }^{39 r}$ la tierra en aquel lugar que conbençerí- / an aun a los muy intelectuales porque asta oy / no a hauido tal y ampasado mucho años y / ay muchos tanto dentro de aquella Ciudad de / Granada como fuera, que jamás an dado fee a / nada de lo hallado, y son sin número los que / no creen nada de ello en comparación de los / que lo creen y aun el Arçobispo esperua ver / exquisitos milagros en esto como luces o mú- / sica del Cielo o descender Ángeles visible- / mente como lo trato conmigo algunas veces. /

\section{Puntos asta el 13. /}

Junto todos estos, porque parece que todos to- / can a la lengua y nación áraue queriendo / la en gran deuer y apoyar sin fundamento / no porque la nación Áraue no sea apta ${ }^{109}$ para / qualquier bien si se rindiesse al yugo del e- / uangelio y la lengua es galana copiossa y afectu- / ossa. Pero como oy está casi

${ }^{108}$ En el margen del manuscrito de Madrid: «Qualquier milagro / tiene el de(?) / referir a Cristo nuestro / Señor di y (?) / ta cruz situ(?) / (?) tanto más / cierta palabra se / ren de verdad en lo / que pretenden cen(?) / (?) (?) si / (?) y aprobados / están estos por el / ordinario y con ri- / guroso examen y / de (?) (?) / (?) comprobaron / y muchos fueron / ha (?) y / notarios que (?) / la forma deuida fu / (?) a (?) / (?) (?) y / decir que esto de mi- / lagros esta a es le / propósito es suma / maldad y más a / cosa actuada y de- / terminada. /

»Si (?) (?) la le- / tra de los libros no / prometen lo mucho / (?) de milagros / luego como se dan / en (?) sino pasa / (?) nos (?)mos (?) a auido y se la comprouado y / aprobado con (?)» (fol. 100v).

${ }^{109}$ En el margen del manuscrito de Madrid hay una anotación a este párrafo pero debido a la tinta de la letra de la otra cara no se puede leerse bien (fol. 101r). 
toda ella es enemiga / del euangelio y tan contraria como se ve //39v el decir que a de uenir un Rey oriental Á- / raue con su escrito de Árabes sujetando ${ }^{110}$ / el Orbe, assi como es perniciossissimo para / estos reynos por hauer tantos millares desta / nación en ellos que no se an tendido al / euangelio como se desea así también lo es para / esa silla Aposthólica por tenerlo leuantados / contra la Yglesia no solo a los Árabes orien- / tales sino tantos judíos seismaticos u here- / ges dudando si esta estabilida sobre la firme / iedra pues diçe esto de ella nuestra Señora y atreuien- / dose a acometella y enbarla por barias vías. /

Andan en España entre los no bien conberti- / dos ${ }^{111}$ librillos de Profecías de su engañador y de / otros que ellos tienen Por profetas, que diçen / que jamás asta la fin del mundo dexara de / hauer en España verdaderos seguidores de Ma- / homa, hermitas y oratorios suyos y esto aunque / más los atormenten y maten y que ande le- / bantar cabeá y sujetar a través estos Reynos / destruyendo la ley euangelica y a esto parece $/ /{ }^{40 r}$ que tiran todos los puntos dichos. /

Confirmase más esto con lo que dice en el punto / doçe que los judíos que crucificaron a Jesús / ellos ni sus descendientes asta el Juycio no se / saluarían, que es tan claramente contra la uer- / dad de la Sagrada scriptura del nuevo tes- / tamento y descubre el natural odio que tienen los / Mahometanos a los judíos por serles tan con- / trarios a su se[c]ta la qual creen ellos que es la / perfection de la ley de Moysés y del euangelio. /

Puntos dende el 14 hasta el 24. /

El hauerse hallado aquel libro illegible $\mathrm{y}^{112} \mathrm{de}$ / cir que se fatigarían por entenderle compeni- / tencias descubre más ser todo engaños y mara- / ñas y tramas mal hurdidas puestas tan / indignamente en ta sagradas bocas de verdad / como la de la Sacratísima Reyna de los Ángeles y Santiago. / Lo del Conçilio $^{113}$ es claro apelar ad futurum con- / cilium con tan pernicioso error como lo es / el decir que entendido este libro illegible $/ /^{40 v}$ conocerán que

${ }^{110}$ En el margen del manuscrito de Madrid: «No los libros (?) / esto como el lo di- / ze a quedado lo di / xeran obra lo que el exagera ni ya ay / esta nación después / de la expulsión de los / moriscos que (?) (?) / ser (?) a España / ni a la silla Apostólica» (fol. 101r).

${ }^{111}$ En el manuscrito de Madrid: «Los incrédulos / judíos y que no se / reducen (?) los que / se diçe que no se / (?) / (?) / (?) / do es católico esto / y conforme a lo es- / cribe (?) no refiere / con (?) (?) que / y como se dize / en los libros del / sacromonte como / se verá en ellos / mismos» (fol. 101v).

${ }^{112}$ En el margen del manuscrito de Madrid: «No diçe esto los li- / bros ni como el / lo dize» (fol. 102r).

${ }^{113}$ En el margen del manuscrito de Madrid hay un texto que no se puede leer bien (fol. 102r). 
hauían entendido mal la expo- / sition del testamento viejo y nuevo y seguido la mal. /

\section{Puntos del 25 al 30. /}

Eran $^{114}$ los que escriuieron estos libros elegantes / Aráuigos orientales no tan praticos de los / lugares santos de Jerusalén y que se esmera- / ron en el estilo, aunque a cada passo ponen cosas / no tan pertenecientes y eregibles como son lo de la / Naue y su ìloto, lo del mandar la Virgen a / Santiago que entrase en España por la parte / oriental della. Que puiesse los libros donde / por el illegible resucitasse un muerto que / era obligalla irlos poniendo de paso empasso / y su le dixo donde los hauia de poner y que auía / de Resucitar el muerto era el decillo assi sin / fundamento, el mandalle predicar sin fru- / to y salir por la parte contraria. /

\section{Puntos 31. 32. 33. /}

$\mathrm{Si}^{115}$ fuera Verdadera toda esta historia a $/ /{ }^{41 \mathrm{r}}$ agrabio se hubiera hecho a la Virgen y a el Após- / tol en calificarlos huesos y çeniças pues dado / por auténtico este libro por aquel a quien toca que / es el uicario de Cristo en la Yglesia, quedarán / calificados el monte y los huesos por tan subli- / mes personas y hauiendo visto esto el prelado / deuía hauer acudido a essa sana silla como / se lo mando con espresas palabras el Concilio / Tridentino (Pace ipsius dixerion) por cartas / suyas escritas al Rey, cuyas copias tengo, y / por el bulto que le embió el papa Clemente 8 / el Año de 1603 consta claro que no hauía dado / el auiso conveniente a essa santa silla Apostólica. /

${ }^{114}$ En el margen del manuscrito de Madrid: «Otros contrarios / an dicho que el esti- / lo no es buen Árabe / y que eran bárbaros los / que los compusieron / mezclando (?) / las elegantes (?) / y (?) los con (?) / moderno mo- / risco y es dispara- / te aquí con (?) lo / contrario. Lo de- / más no lo dizen así / los libros y en la / forma que lo dizen / no tiene cosa in- / digna y se darán / exemplares de la / (?) de escritura / con que asimili que / dará conuencido» (fol. 102v).

${ }^{115}$ En el margen del manuscrito de Madrid: «Aunque sea verdade- / ra la historia que se es- / criue y como se es- / criue en estos libros / del sacromonte / y se visto que si da / su Santidad por au- / tentico esto crece- / rá a más el (?) /do de califica(?) / las reliquias que se hallaron con estos libros. No se le que (?) (?) fue / (?) la potestad en quanto a la calificación de las reliquias que le toca / de depecho antes se la confirmó su santidad (?) (?) las / calificase conforme al Santo Concilio de Trento y según las laminas y //102v otros instrumentos / que con (?) / (?) (?) / viere despachado / en Ferrara a 1 de / junio de 1598 y / con (?) santi- / dad estaua informa- / do de la de los (?) / y la res(?) (?) di- / cen este (?) y fun- / dado (?) / (?) y con noti- / cia de los reyes y / de toda España cali- / ficó el arzobispo / las reliquias sobre / (?) diligen- / cias y (?) / (?) años al / de 1600» (fols. 102v-103r). 
De los demás puntos asta el fin. /

Viendo tan claramente la poca fee que se pue[de] dar a / este libro y los errores contenidos en los puntos / no será necesario decir mucho en los siguientes / llamar al Río Darro, Teber en Aráuigo, pa- / labra no tan husada de los vulgares desta / lengua para decir oro, que ella en elegante / Aráuigo significa oro fino parece que el que la $/ /^{41 v}$ puso affecto poner término que marauillasse / y hiciosse creer que dende el tiempo del Após- / tol se llama río de oro, que eso denota darro / corrompido de las dicciones de auro porque / en ${ }^{116}$ realidad de uerdad se pesca en sus Are- / nas oro muy fino hasta este tiempo y son mu- / chos los testigos desto. El coloquio con el / resucitado y el poco propósito y fructo de / esto y el nombrar a Jesús hijo de Dios y el / decir el muerto que goçaua con él deuiendo / decir por él, descubren ser más cosas de Nesto- / rianos y otros herejes orientales que ni- / egan la diuinidad de nuestro Redemptor. /

Si fuera verdad el hauer estado en aquellas / quebas 40 días el Apóstol fuera aquella cu- / eua la primera y glesia de España pues a- / uian de hauer ofrecido sus sacrificios en / ella en tantos días el apóstol y sus discípu- / los lo qual es contra la opinión tan reciui- / da del pilar de Çaragoça. //42r

De los sellos queda dicho de las palabras / de ellos ecclesiae sto inditio non emim scriptu- / ra sacra est digna sigillis ${ }^{* 117}$. /

\section{Del libro ensalçamiento. Cap. 4 /}

Del título deste libro es elevación o ensalçamiento / de la Virgen María a los Altos secretos de Dios / su historia la pondré por conclusiones [al margen hay una llamada pero no se puede leer] como $^{118}$ el libro / pasado. /

${ }^{116}$ En el margen del manuscrito de Madrid: «Si es cierto que se halla / oro en las arenas del / darro y muy fino / de que se (?) / el árabe le deue / el nombre Teber / que lo significa / el misterio que es lo/ pudo tener si lo / considerose (?) / afición no lo a(?) / bayera a poco pro / (?). Son mu- / chos (?) / los lugares aunque / afirman la diui- / nidad en Cristo / estos libros y ex / presanmente le lla- / ma el fundamen- / tum ecclesiae hijo / de Diosm así lo / traduxo el mis- / mo y no ay donde / y el estar gozose / con Cristo no es / término Nesto- / riano. San Pablo dixo desi- / derium habeas / dissolui et ese / cum Christo. / La de no(?) del Pilar / no excluye esto(?)» (fol. 103v).

${ }^{117}$ En el margen: «A lo que escri[be] / el P. Dr. Viegas / aquellas palabras / de Alipsi, et vidi / tro sedenti in (?) / (?) (?) / et foris signatum / (?) cap. 5».

${ }^{118}$ En el margen del manuscrito de Madrid: «No dize es tal / título deste libro» (fol. 104r). 
1. Dice que contó la Virgen / a los Apóstoles que fue lleuada ${ }^{119}$ por el Án- / gel Gabriel en un carro triunfal a ver los / Altos secretos de Dios. /

2. En la descripción deste carro de muchas parti- / cularidades ${ }^{120}$ que ni se puden tomar metha- / phorica, ni alegóricamente se gastan muchas / ojas deste libro con título de que lo dice la Virgen. /

3. Pinta los lugares por donde fue lleuada como / pintaron ${ }^{121}$ los poetas gentiles los campos e- / lisios o como pintó Maoma su subida / al cielo en su libro intitulado Almijharagi // $/ 22$, al qual imita este en muchas cosas. /

4. A cada ${ }^{122}$ cossa que deseaua ver la Virgen o le pre- / guntaua el Ángel si la quería ver respon- / diendo ella de sí le deçía pues di no ay otro dios / sino Dios, no ay otro uençedor sino él. /

5. Encontrose ${ }^{123}$ con Adán y dice que bio en sus lo- / mos una luz y marauillada preguntó qui- / en era aquel y el Ángel le dixo que era su padre / Adán y aquella luz, la luz de la encarnación. / Y mandó el Ángel ${ }^{124}$ a la uirgen que fuesse a / açelle Reuerencia y ella se llegó abesalle / la mano y Adán no se la quiso dar sino se / la puso en la Cabeça. /

6. Muestra el infierno esta em parte alta / cerca de los campos elíseos o çielos de entrete-/ nimientos y descriuile. /

${ }^{119}$ En el margen del manuscrito de Madrid: «No ay como dicen / fol(?)zala (?) / tal (?) el libro» (fol. 104r).

${ }^{120}$ En el margen del manuscrito de Madrid: «Lo que dize se / puede entender / metafórica y ale- / góricamente si / se mira con (?)...» (fol. 104r). El resto del texto no se puede leer bien.

${ }^{121}$ En el margen del manuscrito de Madrid: «Esto es falso que / es muy de (?)» (fol. 104r).

${ }^{122}$ Sobre la última «a» hay un «1» que es una llamada a una anotación en el margen: «1. / Hace a la uirgen / ignorante y me- / nor que el ángel / i quita a JHS / la diuinidad».

${ }^{123}$ Sobre la primera «0» aparece un «2» que es una llamada a una anotación en el margen: «A fecto procurar / hacer a la virgen / ignorante, menos que / los Ángeles y menor / que Adán».

${ }^{124}$ En el margen del manuscrito de Madrid: «Todo esto se (?) / (?) muy dife- / rente mande que el / (?) dize que / (?) el Padre / Marcos de casti- / llo calificador del / santo Oficio y insig- / ne theologo que fue pro- / uincial de la Com- / pañía de Jhs, el / P. Diego (?) / (?) calificador / y insigne theolo- / go de la Compañía, / el P. Hermando / de Mendoza de la / misma compañía / hombre muy docto, / el P. Fray Pedro / (?) (?) a (?) / serna prouincial / de los mercenarios [sic] des- / calzos insigne en / letras y teología / y otros an visto (?) / fil y (?) / dución deste libro / y todos lo an teni- / do por seguro y [tachado] de que(?) se dize que es no hallan porque / no predicar que esto toda (?) santidad al declarado y a (?) / se abra de estas en la Virgen Santísima noforma ignoran- / cia sino antes ay en este libro singulares alabanzas suyas» (fol. 104v). 
7. También muestra que no ay almas en / el infierno hasta el día del Juicio. /

8. Dice que los demonios no atormentarán en $/ /^{43 r}$ el infierno porque por ser ellos también / atormentados no guardaran justicia. /

9. Los que atormentaran dice que serán unos / Ángeles morenos criados de Dios para esto. /

10. Preguntó la Virgen por satán y dedixeron el / que estaua en más interiores fuegos y tini- / eblas y que si le quería ver; respondió que si. / Venido le descriue; y le preguntó la Birgen / como entró en el parayso y engaño a nues- / tros Padres y otras preguntas tales. /

11. Dixole la Uirgen al demonio, que se aRe- / pintiesse que ela rogaría a Dios le perdo- / nase y el huyó luego. /

12. Subiendo al cielo, pidió al Ángel le mostra- / sse la diuina esencia; y el le respondió que / nadie veya a Dios claramente alta después / del día del Juicio. /

13. Eleuola <a ver > quanto se podía de Dios, alçandose / un belo o luz quele cubría. /

14. Halló allá con su Hijo que estaua en lo más alto del trono / de Dios. //43v

15. Vio el original del libro illegible en el trono de Dios. /

16. Por este libro y el illegible dice que sea de con- / uertir el mundo a la uerdad y la ley ser una. /

Raçon de lo apuntado en este libro. /

El estilo deste libro ensalçamiento, al prin- / cipio parece graue y grauemente puesto y más en / boca de la Virgen y el autor y autores ha- / uían leydo la su vida del falso Maoma en / el animal Alboraque guiado de Ángel / Gabriel como el fingió el cielo, (?) auían / oydo recontar decirse (?) porque en / todo le imita y se uee que pretendió quitar / la diuinidad a Jesuchristo Nuestro Señor, y dismi- / nuir a su santíssima Madre como queda a- / puntado y por lo errores y ignorancias se / vee ser cuna junta de barios herejes que / afectaron juntar cosas elegantes con igno- / rancia como son el decir que no son los de- / mo- 
nios los que atormentan en el infierno / y que los atormentadores son Ángeles [tachado: mo] buenos $/ /^{44 r}$ [esto sobra: renos], que dixo la uirgen al demonio que / se arrepintiese, que ella rogaría a Dios le / perdonase y otros tales. /

Del libro illegible Cap. 5. /

Llamo a este libro illegible porque en el libro / que he dicho que es su historia, dice que no se- / a de acertaría a leer hasta que se junte aquel / concilio General. /

Tiene muchos y galanos sellos embarias / formas hechos inguidos vanos en otros de / los que dixe de Salomón y en algunas ojas / no ay otras cosas scriptas sino estos sellos / al principio como los demás libros tiene / sus título que es Haquisat Al ingili, que / es verdad del euangelio o certidumbre en / la primera oha de las escritas en un sello / de los dichos tiene ocho elegantes versos / en Aráuigo que declaran su excelencia / en esta forma. Certidumbre del euangelio / que derribara todos los estándartes. Di- //44v chosos el que reciuiere con spiritu y coraçón / y desdichado del que no lo creyere. /

Pone otros encarecimientos en estos ver- / sos la forma de la letra illegible la puse / arriba. /

Raçon deste libro. /

Este solo descubre ser imbención y traça de / herejes amigos de perturbar la paz com / barias nouedades ${ }^{125}$, et licet ipse, dice el a- / postol, aut Angelus ebangelicet bobies pre- / ser quam quod euangelizatum est Anathe- / masit. /

Acauaré todo lo de los libros con lo que me / pasó sobre el libro de Plomo aovado que / dicen ser una oración de Santiago. Auía / dicho los intérpretes al Prelado que en / est aoración estauan estos quatro nombres: /

Los quales decían no poderse atribuir a otro / que Dios ${ }^{126}$, o quien fuere

${ }^{125}$ En el margen del manuscrito de Madrid: «Este libro esta- / ua escrito antes / que (?) esto san / Pablo según se / dize y dejemos que / san Pablo escri(?) / esto se escriuieron / escrituas o ra- / çon sagradas y de- / mas (?) / (?) doctores (?) / desto (?) / que no (?)» (fol. 106r).

${ }^{126}$ En el margen del manuscrito de Madrid: «Bien fuera que ci- / tara el libro / Mahometano para / que miramos sin / más verdad lo que / dize que otros (?) / que se ve que no lo (?) / de los que a dicho, / más quando lo fue- / se no porque el ma- / hometano dice a / mahoma atribu- / tos diuinos de / (?) ellos de / serlo y oir (?) / a dios y mal dados / a otro, mas (?) / (?) porque los mo- / hametanos 
unido de tal su- / erte con él que fuesse ynseparalle, y aun- / que ellos en el genero masculino que están / denotan deydad cada uno en su significa- / cióny son propios del Redemptor, mos- / tré al Arçobispo en un libro de Mahome- / tanos como todos ellos por su mismo orden / los atribuyen y dan a su falso engañador / con infinitos otros, que son del uerbo en- / carnado solamente; y le auisé como esta o- / ración que andaua muy pública en las / manos de mucha gente de España era bastan- / te ocasión para que los no uien conbertidos / de la nación de los Árabes se persuadiesse / que era diferente el euangelio que ahora / tenemos del que predicaron los Apóstoles / y de lo que enseñó Jesucristo, que es lo que los / Mahometanos creen. /

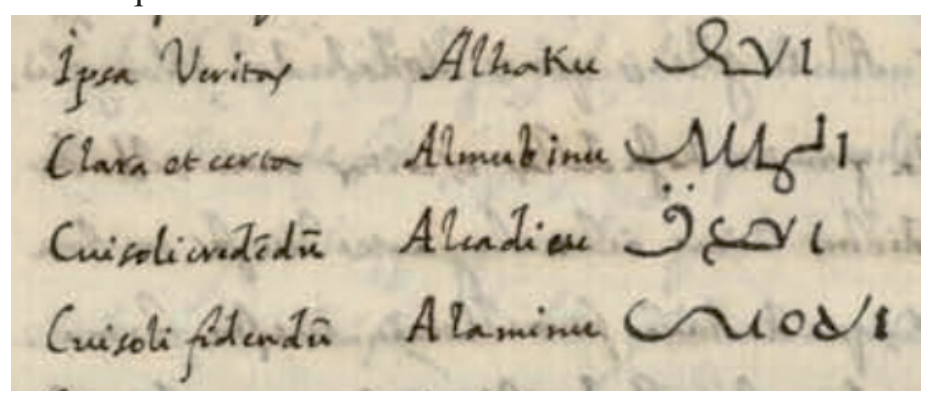

Esto es Beatísimo Padre lo que con verdad //45v e podido decir de lo hallado en Granada. /

Cap. 6. Quam unidos están $\operatorname{los}^{127}$ / libros y láminas con los huesos / y con lo de la torre y con los da- / ños que de todo naçen. /

Considerando quam trauadas están todas estas / cosas entre si como se ue por las laminas y cubier- / tas de los libros y que no se puden diuidir ni / apartar pues el mayor testimonio de que / aquellos huesos son de tal o tal santo consta / destas láminas y o de otra cossa y ellas / mismas dicen que aquellos

no / atribuyen a Ma- / homaser diui- / no, tienenlo per- / zona y por pro- / feta, siendo en- / gañador y mal- / dito de Dios» (fol. 106v).

${ }^{127}$ En el margen del manuscrito de Madrid: Bien se pudiera / dscutir el juizi(?) / (?) de los li- / bros y el de las reli- / quías y su santidad / los (?) (?) / (?) que a mi(?) / y con (?) lo que (?) / (?) (?) / es muy cierto que / están tan unidos / las láminas y libros / y el pergamino que / se halló en la to- / rre que no pueda / ser ciertas las reli- / quías si los libros / y láminas y / pergamino no / son de aquel tiem- / po y que se deue mu- / cho crédito por la / coherencia con / las reliquias / y obliga a enten- / der la consideranción / destos libros c(?) / afición y / así deue su san- / tidad hazer el / examen (?) / consideración y a- / tención mas esto nade de la verdad del hecho y tuve funda / en nada fingido, ni el arçobispo excedió por que siempre dio que (?) / de todo muy abundantemente y no calificó los libros porque no le / tocaua y estaua reseruado justamente a su santidad en quanto a / la dotrina dellos, pudo calificar y así calificó las reliquiaslegitimamente» (fol. 107r). 
escriuieron los / libros y por ser tan claro esto no lo dilato más / y el mismo doctor Madera que defiende estas co- / sas confiesa que no pueden apartar antes / que execute el Prelado la calificación. Le hice / notable instancia que aduirtiesse los errores / que auía en los libros y la trauaçon que tenían $/ / 46 \mathrm{r}$ con lo demás y los graues daños que resulta- / rán a estos Reynos y a la Yglesia, y uiendo que no / me daua las orejas que yo desseaua en negocio / tan arduo y graue, y que quería proseguir a la ca- / lificación diciéndome que eran diferentes los / libros de los huesos y çeniças, me salí de Granada / sin su beneplácito así porque no se dixese que / un sacerdote de la Compañía los hauía interpre- / tado u authoriçado como por poder de lexos escri- / uí al Arçobispo mi pareçer para que constasse. / Hicelo así por una larga carta que le embié / desde Valladolid y uiendo por su Respuesta que / proseguía en su intento, ora fuesse por pensar que / no entendía yo los libros tan exactamente y que / otros interpretación o interpretarían de otra su- / erte o por lo que es más probable porque te- / nía puesto todo lo hallado en aquella Ciudad / en los ojos del Rey, Prelados y grandes de Espa- / ña en tan summo grado que era difícil el des- / haçello y particularmente hauiendo gastado $/ /^{46 \mathrm{v}}$ tantos millares de ducados, así en acomodar / las quebas como en authorizarlo todo, fui forza- / do de mi conciencia y por consejo de muchos / doctos y (?) dar auisso al Tribunal su- / premo de la Santa Ynquisición el qual me / embió a llamar y en Cassa del Inquisidor / Zamora, oy presidente de Granada, reco- / nocí una Carta que sobre esto auía escrito a este / supremo Consejo de Inquisición y siendo examina- / do por particular interrogatorio respondí / a las dificultades que se me oppusieron y / añadí al fin de lo profesado, que suplicaua a / aquel Sancto Tribunal que aduirtiesse / y considerasse que no tenía necesidad la Y- / glesia de Dios en este tiempo de nuebas re- / liquias aunque fuesen certíssimas de los / Apóstoles, y le estaua muy bien que no se / renouasen heregías antiguas o se imben- / tasen otras, y aunque gratificó el consejo / mi ida y trauaxo, cosa no usada del Collegi / de las palabras que últimamente a mi des- $/ /^{47 \mathrm{r}}$ pedida me dixo el inquisidor General Por- / tocarrero que estaua persuadido por el Ar- / çobispo a apartar los libros y láminas de los / huesos y çeniças y de lo de la Torre porque / me dixo que podía ser que las Reliquias fue- / sen de santos y que herejes sauiendo que lo / eran hubiesen puesto allí aquellos libros / para autoriçar su doctrinas y esto se (?) / imposible sea moralmente hablando y quan / dañoso y peligroso porque como dixe al inqusidor / como se pude decir que en la una parte que toca / a las reliquias diçe la lámina la verdad en / decir que son de tal o tal santo y mienta en / decir que esos santos escriuieron tal o tal li- / bro en una diçe: Pasus est in hoc loco illi / pulitans. Dicis Thesiphon dictus prius quam / comberteretur Abenatar, Dici Jacobi Ap- / postoli discipulus virliteris et santitate / preditus, si a todo esto desta lámina se le da / fee 
como sele puede negar esa misma fee a / lo que se sigue en la misma lámina $/ / /^{47 \mathrm{v}}$ Plumbirabulis scripsit librum illum fun- / damentum ecclesiae appelatum, y más aba- / xo: quórum puluis et liber sunt cum pul- / veribus Divorum martyrum in huius sacri / montis cauernis; y en la lámina de la cubi- / erta del libro essentia Dei dice: Quem / diuus Thesiphon Apostoli Jacobi discipulus / in sua naturali lingua Arabica, Salomo- / nis caracteribus scripsit et alium funda- / mentum ecclesiae Appelatum qui in / huius sacri montis cauernas jacet. Lo mismo / digo de la otra lámina: Pasus est marty- / rium in hocloco illijulitano dibus Ceçilius / santi Jacobo discipulus verliteris linguis / et sancitae preditus Prophecias diui Jo- / annis Apostoli comentauit quae sunt po- / sitae cum alijs reliquijs in sublimiparte / in hauitabilis turris Turpianae. /

Como el Prelado [h]a sido presidente de las / audiencias de Granada y Valladolid y / saue en negocios lo que combiene supo //48r caminar en este asta alcançar su intento, / porque el Consejo de Inquisición no le pudo prohibir / lo que acerca de las reliquias, le da el conci- / lio tridentino y como el inquisidor ordina- / rio tenía los libros para examinarlos, aunque / le [tachado: embió] imitio que no hiciesse mención de ellos en / la calificación que no fue poco. El Nuncio / de essa santa Silla Apostólica que entonces era / hiço gran contradición a la calificación por / solas las dificultades exteriores que le a- / uían propuesto sin sauer nada de lo dicho / de los libros porque no pude darle auisso por / ser solo y hauer estado en la cama enfermo / muchos días y ansí bençió la importuna di- / ligencias humanas conocida de tal suerte / del Nuncio que $<$ me $>$ an certificado que impor- / tunado de personas graues que [tachado] < dexase > / al Arçobispo calificar las reliquias / dixo: Faccia egle pure sopra sua conscien- / tia vada, poiche non vuole spettare / che sia auisato nostro Signore. Auisé a la $/ /{ }^{48 v}$ F.M. del Antecesor de V. S. por carta particu- / lar de los daños que podían resultar y infor- / mando el illustrísimo Gemnasio que fue el / Nunçio que sucedió al pasado y dando su / Ilustrísima auiso al papa Clemente despecho su Santidad / el Breue que pongo aquí: /

Archiepiscopo Granatensi. /

\section{Clemens Papa. 8. /}

Venerabilis frater salutem et Apostolicam Benedictionem. / Sivera sunt quae nuntiantur habes cerse inqui / pie glorieris, tua Dioc, iam in die aprincipio / nascentis ecclesiae retrasum abdictiemae sub- / terram nunc demum diuina prouidentia / novum tibi dei thesaurum de monstiatis / testumonium quae ese exemplar quodam una / cumeo inventum vetustate probatum / satis 
hae casserunt tantam nouis poten- / de cupidetatem innitjcent ut in horas plus / q. accendarum moraq. nobis omnis sit moles- / ta adeo ad tan praeclara tan santa degustanda $/ /^{49 \mathrm{r}}$ animae exardecit, Aequin est etiam nouis un sei entibus / nichil eius modi in publicum proponi quos ad com- / munem ecclesiae causan pertineat. Nostro / q. illud reseruatum iuditio notri et nostra / id fieri deuere autoritate. Quam obrem hor- / ta murte quae tua est ergo santan hanc se- / dem obsevantia, at q. in decem pietas. Ut / offiuij sui menor exemplar ipsum curres ad nos / praeferendum quam primum, illud que vene- / rabili frati Archipiscopo sepontino nro. Apos- / tolice sedis Nuncio tradas ut matun con- / silio statuatur quid publicae combeniar uti- / litati quid ecclesie dei. Habeuis tu quoquae / fidem eidem Archiepiscopo in hijs q. nostro / mandato ex illo audies, tibique persuadiuis / noste paterna charitate nostra plen completi / fouirique asidue examino, datum Roma / apud santm Petrum, sub Anulo Distoris / deo decimo quinto novembris 1603. Ponti- / ficaus nostri Anno duodécimo. /

Deste $^{128}$ breue y de unas cartas que el Arçobispo $/ /^{/ 9 v}$ escriuía a la Magestad del Rey Philippe cuyas / copias tengo se collegen claro los puntos siguientes: /

1. Que su santidad no estaua informado de la graue- / dad deste negocio e importancia del por el / Arçobispo como de deuía ${ }^{129}$. /

2. Que calificó las reliquias inconsulto Pon- / tifice ${ }^{130}$ mandadole lo contrario el Concilio / Tridentino en cossa graue como lo es esta tanto. /

3. Que pretendía autoriçar y calificar los libros ${ }^{131} /$ sin hauerse examinado su dotrina por essa / Santa Silla como se deuía. /

${ }^{128}$ En el margen del manuscrito de Madrid: «Este viene solo en / orden a pedir su san- / tidad los libros sien- / do como es ordenado / por diferente notario / que las otras nos (?) / (?) que el pontífice dexa- / sse de tener la noti(?) / consta de otros bienes y / que dio D. Pedro Guerrero, em- / biado a (?) el (?). /

»Mas de tres años antes de este breue estaban calificadas / las reliquias, fue la sentencia publicada a 3 de abril de 1600 / después de cinco años de examen, procesos y exactas diligen- / cias y de (?) cuenta a su Santidad, a los reyes y...» (fol. 110v). El resto del texto no se pude leer.

${ }^{129}$ En el margen del manuscrito de Madrid: «Es faso / esta su santidad infor- / mado de todo y consta por / (?) respuestas» (fol. 111r).

${ }^{130}$ En el manuscrito de Madrid: «Esto es falso porque / dio de todo aun desde / el principio que asta su / santidad y con (?) / de comisión calificó / las reliquias» (fol. 111r).

${ }^{131}$ En el margen del manuscrito de Madrid: «Es también falso y / consta de lo mismo/ antes y papeles parti- / culares que siempre se / dexó esto a su Santi- / dad que lo tenía reser- / uado en (?) / que (?) Castro / en la calificación de / las reliquias dado / en Ferrara a 1 / de junio de 1598 / y ootros antes y des- / pues». (fol. 111r). 
Los daños que a estos reynos y a la iglesia / pueden venir de esto los dixe en un memo- / rial que di yo en mano propia a su Magestad el / año de 1604 en la Ciudad de Valencia / y dexandolo que en aquel memorial dixe / pondría que ad verbum lo que toca a estos daños. /

Por lo qual (digo en aquel memorial) se / [h] alla obligado el dicho P. Ignacio como / verdadero hijo de la santa iglesia Romana $/ /^{50 \mathrm{r}}$ y fidelissimo vasallo y humilde Capellán / de Vuestra Magestad a representarle dos cosas con toda / la fidelidad y verdad. /

Primera. Que supuesto que lo dicho arriba / que ay en algunos de aquellos libros erro- / res y Heregías puestas ${ }^{132}$ en la boca de la ma- / dre de Dios y de Santiago su se les da qualqui- / era fee a crédito saldrán quando nos piensan / algunos ereges de los curiosos que aya, y pe- / diran les dexen sacar originalmente toda la doc- / trina de los libros. Y dirán que ellos buscarán / fieles interpretes doctos en esta lengua quales / los ay artos en oriente, y con $<$ solo $>$ esto esto darían en que / entender a la iglesia y sulico al Señor que no sal- / ga alguno compedir esto por sola la califica- / ción de las reliquias, por estar tan traua- / das con ellos, y por lo que se [h] a publicado por / todas partes, que todos mueren por uer qual / fue la doctrina de la madre de Dios y / de los Apóstoles que diçen están estos libros $/ /^{50 v}$ bien clara se ue quam graue es este incombeniente. / Y aviendo puesto en el memorial lo del / Rey Árabe que queda dicho con lo demás que / toca a esto añado más claros se uen en estos / los grauísimos inconvenientes: /

1. Tener soliuantados los ánimos de tantos ${ }^{133} /$ millares de Árabes como vuestra magestad tiene en es- / tos reynos que todos lo entienden y sauen / que no ay secreto entre ellos en estos. /

2. Que se persuadan con maior pertinacia que $\operatorname{asta}^{134}$ a- / quí que la ley euangélica no es la que sigue oy / la yglesia. /

${ }^{132}$ En el margen del manuscrito de Madrid: «El supuesto es fal- / so, y con todo el / argumento antes / ay doctrina en los / libros expreso con(?) / se confunde todos / los (?) antiguo / y no damos como lo / an dicho muchos doc- / tissimo que an visto / las traducciones. /

»No porque los erejes / pidan los libros a su / Santidad ni el rey / nuestro señor que los (?) / ne debajo de sus lla- / ues se los mandara / entregar para que los / interpretes que / esto se hara por ca- / tólicos y todo lo que / a ello toca con la / atención y madu- / rez que el negocio / requiere» (fol. 111v).

${ }^{133}$ En el margen del manuscrito de Madrid: «Ya no ay moros (?) / en España ni estos / libros los po(?) le / (?) a (?) sino de (?) / error y no la (?) a / la fee católica que está / en ellos expresa contra / sus errores» (fol. 112r).

${ }^{134}$ En el margen del manuscrito de Madrid: «Por los libros se declara / que la fee que tenemos en / la iglesia siempre fue / una y lo a de ser» (fol. 112r). 
3. Que el demonio halle puerta permitiendo- ${ }^{135} /$ selo el señor por los pecados para nuebas he- / regías y leuantamientos. /

4. El apelar ad futurum concilium que es principio $^{136} /$ de todas las eregías por el pretender a- / partarse de su Caueça que es el uicario de Cristo / y no obedeçelle ni creer lo que el les ordena. /

5. El deshaçer las demás naciones y apoyar ${ }^{137} / / /^{1 \mathrm{rr}}$ a los Araues por boca de la Virgen cuya se[c]ta / es oy tan estendida y contraria a la ley euan- / gélica que casi no ay de ellos cristianos ningu- / nos fieles. Y aue V. Santidad de quan peque- / ña centella de ${ }^{138}$ qualquiera error se suelen / leuantar llamas de heregías y más están- / do el mundo tan lleno dellas ${ }^{139}$ y tan amigo / de nouedades y teniendo España tantos tan mal / conuertidos. Assi del judaísmo que a ueçes / brotan en sus errores y tan inumerables / de los descendientes de Áraues que todos se / persuden que se están en sus errores y los / unos ni los otros no creen a la uerdad del euan- / gelio y qualquieruerdad semejante los hace / aferra<se $>$ más en su pertinençia. /

Cap. 7 y último del reme- / dio que se pretende. /

No es mi intento Beatísimo Padre persudir que se / me de a mi sola fee. Dixe en la carta que es- //51v criuí al Arçobispo y en la procesado en el tribu- / nal de la Inquisición y últimamente en el memorial / que dí al Rey que aunque los otros intérpretes / que a auido sauen más de la lengua Árauiga / que no yo, no sauen nada de las letras sagradas / ni de otras facultades necesarias para la inter- / pretación ${ }^{140}$. /

${ }^{135}$ En el margen del manuscrito de Madrid: «Todas las herejías se / confunde con la doctri- / na que ay en los libros / (?) con ello / el demonio» (fol. 112r).

${ }^{136}$ En el margen del manuscrito de Madrid: «Este es disparate, no / ay tal en (?) / apoya la autoridad / del vicario de Cristo / y de su sucesores / en clausulas expresas / destos libros» (fol. 112r).

${ }^{137}$ En el margen del manuscrito de Madrid: «Claro se dize en los / libros que esta nación / (?)de son muy e- / nemigos de Dios como / lo a sido y es, pero / que sea de (?) y / lo a di(?) mucho / no ay en esto in (?) / (?)» (fol. 112r).

${ }^{138}$ En el margen del manuscrito de Madrid: «No deshacer los demás / naciones y de la Ára- / be dizen que sea de con - / verter después de (?) / (?) grandes enemi[gos] / de Dios y de la fee» (fol. $112 r)$.

${ }^{139}$ En el margen del manuscrito de Madrid: «Ya está lim(?) fue- / ra de los de la nación / del padre Casas y / la fee en ella está / muy asentada con / (?) Dios» (fol 112v).

${ }^{140}$ En el margen del manuscrito de Madrid: «Quisiera el padre / introducirse por / dueño deste nego- / cio» (fol. 113r). 
Añadí lo segundo que supe porque quando inter- / pretauan que era siempre empressencia del / Arçobispo y de otros por el, deçian quando / topauan

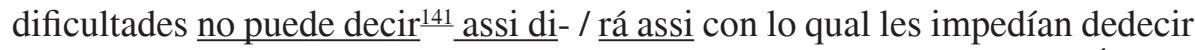
/ con la liuertad la verdad, y más siendo ellos des- / cendientesde los Áraues y temerosos de no / ser teniedos por hombres que deçian contra la / fee como dixeron ellos propios. Detrás dos / cosas se concluye claro lo último que dije que / no están bien ${ }^{142}$ hechas, ni seguras las interpre- / taciones en cossa tan graue e importante della / Yglesia y que (?) forçosso tomar el medio que / allí apunté y es que theologos moços assi de //52r barias religiones como de otros deprendan / en quatro o cinco años la ${ }^{143}$ lengua Árauiga / y con esto se entenderá mi verdad y serui- / rán a la iglesia y a este Reyno no solo en / esto, sino aun en todo lo que tengo apuntado / en vn tratado particular de ello. /

Siendo verdad queanto he dicho, parece que se me / puede preguntar lo que siento desta maqui- / na y ardides del enemigo para perturbar la yglesia. /

Grandes ${ }^{144}$ señales tiene todo ello de antigüe- / dad pero esta no la podemos dar de más tiempo / que de 30040 años acá, porque si la diesse- / mos $^{145}$ de antes de Mahoma o de Lutero se podía / concluir que era Profeta el que la escriuía / pues trae destos dos perseguidores de la / Yglesia antes que fuessen. /

Decir que es invención de Maometanos o moris- / cos de aquel Reyno tampoco me quadra, la / raçones el uer que los libros tienen cosas muy / bien ${ }^{146}$ puestas de la ley euangelica y por términos / que no los usan los mahometanos y son pro- $/ /^{52 \mathrm{v}}$ pios de los cristianos orientales y los errores ${ }^{147} /$ son de los seismaticos de aquellas partes. /

${ }^{141}$ En el margen del manuscrito de Madrid: «Cierto es que con(?) / fidelidad y desi(?) / de sacar la verdad y / diligencia asistía el / arzobispo, y no pro- / curado torçer la (?) / de tal persona se / puede pensar (?) / es cosa maligna» (fol 113r)

${ }^{142}$ En el margen del manuscrito de Madrid: «Cierto es que no se consi- / guió sacar perfectas / traducciones pero / no que no se dessease / y procurase» (fol. 113r).

${ }^{143}$ En el margen del manuscrito de Madrid: «Es buen consejo» (fol. 113r).

${ }^{144}$ En el margen del manuscrito de Madrid: «No puede negar / las grandes seña- / lesde antigüe$\mathrm{dad} /$ grande» (fol. 113v).

${ }^{145}$ En el margen: «No es buena rraçon / deue esta tomarse / de la misma (?) / puesto que se (?) / de es que sea propheta / (?)».

${ }^{146}$ En el margen del manuscrito de Madrid: «Confiesa / no pueden ser / de Mahometanos / ni moriscos porque / contienen coss con- / tra su (?)» (fol. 113v).

${ }^{147}$ En el margen del manuscrito de Madrid: «(?) de erejes pin- / tales que son contra / su errores» (fol. 113v). 
Por lo qual se me hace probale que an sido / varios ${ }^{148}$ los autores de todo esto mezclados / de sismaticos orientales herejes y maome- / tanos de los quales todos suelen venir mu- / chos en España y más aquel Reyno de Granada./

Persuadame más a creer [tachado: aquello] esto el hauer to- / pado yo en estos Reynos y fuera de ellos astu- / tissima y atreuida gente de los dichos. /

Considerando Santíssimo Padre quan asentada esta ya en / Granada la deuoción destos huesos y çeniças / que an calificado y contitulo de hauer ha/ uido muchos milagros los quales para a llegar a la uerdad que se requiere tie- / nen mucho que mirar ponderar y prouar / y los atribuyo io si an sido a la cruz pu- / esta con ${ }^{149}$ tiempo en aquel monte y sauien- / dolos gastos hecho por el Prelado, el asfon- / so de la Ciudad, y de otras convecinas veo el / poco remedio que tiene este negocio quanto $/ /{ }^{53 \mathrm{r}}$ al desarraygar la deuoción y la ya introdu- / cida. Pero también beo los peligros propues- / tos de la doctrina de los libros sino se hace al- / guna grande demostración qual es el prose- / guir Vuestra $S^{d}$ lo intentado por defelice menoria / de su antecesor, de hacer que se lleuen $<1>$ los li- / bros ${ }^{150}$ originales con las láminas a essa santa / silla y examinados ay como se deue el ${ }^{151} /$ señor suyo es este negocio abrirá camino qual / combiene a su remedio y siento por necesario que / no se permitan quedar acá traslados $<2>$ ni ba- / ciados dellos por los daños que se ue en que / pueden ${ }^{152}$ nacer y mientras que se examina / la doctrina desto libros y se ue lo que combi- / ene parece que no se deue permitir que nin- / guno ${ }^{153}$ impri-

${ }^{148}$ En el margen del manuscrito de Madrid: «Contra todos son ex / presamente los li- / bros no pueden ser / mahometanos ni / erejes» (fol. 113v).

${ }^{149}$ En el margen del manuscrito de Madrid: «Que se (?) / si fueron milagros / verdaderos y / si lo son se atribu- / ian a la cruz que / se puso en aquel / monte, no puede / auer mayor (?) / (?) de (?) que / negar los milagros / euidentes y quan- / do no (?) / a santa cosa siendo / de calidad que no / se puede y hechos / con (?) en / comprobación desta / verdad que esta / (?) aueriguado el / prelado en que Dios / no los permitiera (?) / rentes ni los abrara / verdaderos en compro- / vación y testimonio / de cosa falsa» (fol. 114r).

${ }^{150}$ En el margen: «1. / Lo que se (?) principal a V. S. y pa- / rece fue cossa y necesario / (?). /

»(?)man de lleuar / todos loslibros halla- / dos y las láminas y / cubiertas, a essa santa / silla para examinarlo / todo allá como com- / biense».

${ }^{151}$ En el margen del manuscrito de Madrid: «Quisiera el padre / que lo llamara y le / llamaran para es- / to i introducirse / el papa no los a(?) / restos llenar (?) / examinarlos que lo pue- / de hazer por comisrio / y tiene inconvenien- / tes o (?) cosa graues» (fol. 114v).

${ }^{152}$ En el margen: «2. Que no se que- / den aca traslados ni / vaciados de ellos por los / grandes daños que na- / cerán».

${ }^{153}$ En el margen: «3. Que se pro- / hiban los libros que / an salido que tratan / de los libros de plomo». 
ma $^{154}<3>$ nada de ellos ni trate del / hauerse descubierto ni hallado porque dan / con esto asa y abren puerta a los Hereges / para poder pedirlos para uer la doctrina de / la Virgen y de los Apóstoles y ${ }^{155}$ por esta Causa / parece que combene que mandasse V.S $S^{\mathrm{d}} / /^{53 \mathrm{v}}$ borrar de ciertos libros impressos lo $<$ que > dicen en / alauança desto de Plomo hallados ${ }^{156}$ como son / los auores siguientes: /

Cianca en el libro que compuso de seguido / Pineda sobre Job. /

Los dos discursos de la uenida de Santiago / en España sacados de la librería del Condestable. /

Fray Luys de Ariz en la historia de Auila / y otros qualesquiera que ayan tratado de e- / llos, y sobre todo prohíben por ahora el libro / del doctor Madera jurisconsulto, oi, Al- / calde de Corte por ser todo desta materia. /

Esto es Sanctissimo padre quanto me apare- / cido que tenía obligación de representar / a V. Santidad como fiel hijo de la Yglesia y de / essa santa silla a la qual [tachado: a la qual] e ser- / uido Años en essa penitenciarí de san Pedro / y el poner todo esto a los pies de Vuestra Santidad es solo / por la Gloria de Dios, y honrra de $/ /{ }^{54}$ de su Yglesia y bien de tantos millares / de ánimas como ay en España destituydas / de todo socorro para su conversión la / qual impide e impedirá todo lo propu- / esto. Suplicando a Vuestra Santidad humilissima- / mente ponga los ojos en ella, y a mi / como a su fielissimo hijo mande / dar su sanctíssima Bendición. //55r

${ }^{154}$ En el margen del manuscrito de Madrid: «El no imprimirse / está bien hasta la / calificación el (?) / primirse sin estar / condenados en las / tenidose (?) / de certeza claras / no ay porque sea» (fol. 114v).

${ }^{155}$ En el margen del manuscrito de Madrid: «No (?)ran de ver- / los los(?) que son / contra ellos» (fol. 114v).

${ }^{156}$ En el margen del manuscrito de Madrid: «Mejor fuera pro- / hibirle este papel / que están lleno de fal- / sedades y dispa- / rates en materia / de tanta estima» (fol. 114v). 